\title{
Catalysis in Biomass Gasification
}

\author{
E. G. Baker \\ L. K. Mudge
}

June 1984

Prepared for the U.S. Department of Energy under Contract DE-AC06-76RLO 1830

Pacific Northwest Laboratory Operated for the U.S. Department of Energy by Battelle Memorial Institute 


\title{
DISCLAIMER
}

This report was prepared as an account of work sponsored by an agency of the United States Government. Neither the United States Government nor any agency thereof, nor any of their employees, makes any warranty, express or implied, or assumes any legal liability or responsibility for the accuracy, completeness, or usefulness of any information, apparatus, product, or process disclosed, or represents that its use would not infringe privately owned rights. Reference herein to any specific commercial product, process, or service by trade name, trademark, manufacturer, or otherwise, does not necessarily constitute or imply its endorsement, recommendation, or favoring by the United States Government or any agency thereof. The views and opinions of authors expressed herein do not necessarily state or reflect those of the United States Government or any agency thereof.

\author{
PACIFIC NORTHWEST LABORATORY \\ operated by \\ BATTELLE \\ for the \\ UNITED STATES DEPARTMENT OF ENERGY \\ under Contract DE-AC06-76RLO 1830
}

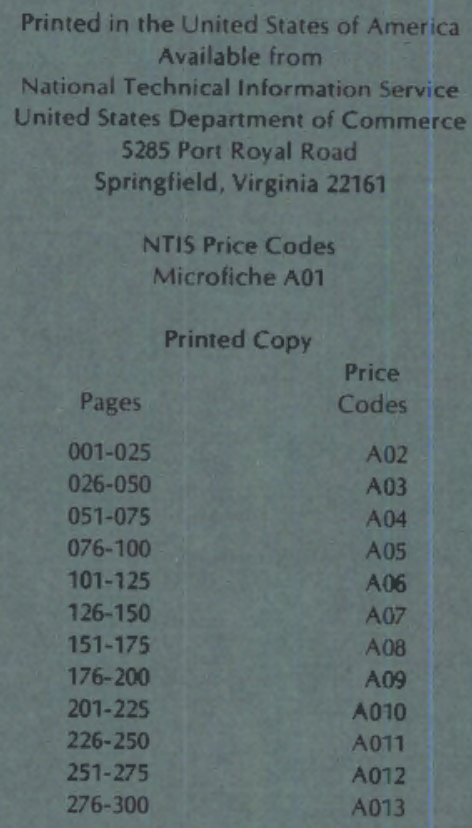


CATALYSIS IN BIOMASS GASIFICATION

E. G. Baker

L. K. Mudge

June 1984

Prepared for the U.S. Department of Energy under Contract DE-AC06-76RLO 1830

Pacific Northwest Laboratory Richland, Washington 99352 
SUMMARY

The Pacific Northwest Laboratory is conducting studies, sponsored by the Biomass Energy Technology Division of the U.S. Department of Energy, on the use of catalysts in biomass gasification. The overall objective of these studies is to evaluate the technical and economic feasibility of producing specific gas products by catalytic gasification of biomass. Catalyst performance is a key factor in the feasibility of catalytic wood gasification processes. This report presents the results of studies designed to gain a fundamental understanding of catalytic mechanisms and of the causes of deactivation, and discusses the state-of-the-art of related catalytic processes.

Experiments with primary and secondary catalysts were conducted in a $5-\mathrm{cm}-$ diameter, continuous-wood-feed, fixed-catalyst-bed reactor. The primary catalysts used in the experiments were alkali carbonates mixed with the biomass feed; the secondary catalysts included nickel or other transition metals on supports such as alumina, silica, or silica-alumina. The primary catalysts were found to influence wood pyrolysis as well as the char/steam reaction. Secondary catalysts were used in a fixed-bed configuration to direct gas phase reactions. Results of the performance of these catalysts for wood gasification in the laboratory system are presented. Secondary catalysts were found to be highly effective for conversion of biomass to specific gas products: synthes is gases and methane-rich gas. With an active catalyst, equilibrium gas compositions are obtained, and all liquid pyrolysis products are converted to gases.

The major cause of catalyst deactivation was carbon deposition, or coking. Loss of surface area by sintering was al so an important factor. Catalyst deactivation by sulfur poisoning was observed when bagasse was used as the feedstock for catalytic gasification. Mechanisms of catalyst activity and deactivation are therefore discussed. Model compounds (methane, ethylene, and phenol) were used to determine coking behavior of catalysts. Carbon deposition is more prevalent with ethylene and phenol than with methane. Catalyst formulations that are resistant to carbon deposition are presented. 
Several types of carbon deposition on nickel catalysts are known to occur in steam-reforming of hydrocarbons. The mechanisms for formation of polymer, whisker, and pyrolytic carbons are discussed.

These studies have revealed promising approaches to the development of effective catalyst systems for gasification of biomass. The influence of process variables, such as char residence time, gas velocity, and biomass particle size, has been shown to be important to the catalytic process design. 


\section{CONTENTS}

SUMMARY

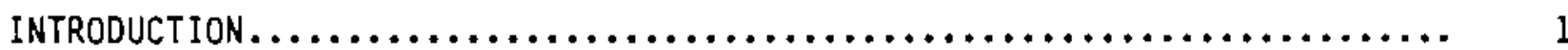

BACKGROUND.............................................

EXPERIMENTAL FACILITIES $\ldots \ldots \ldots \ldots \ldots \ldots \ldots \ldots \ldots \ldots \ldots \ldots \ldots, 3$

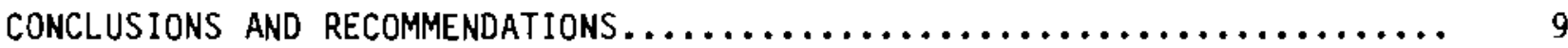

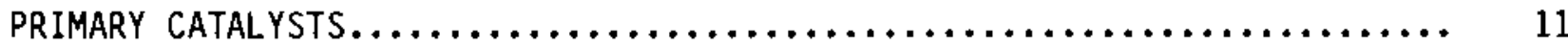

CARBON/STEAM REACTION..................................... 12

Effect of Catalyst Type.............................. 14

Effect of Catalyst Loading........................... 14

Effect of Catalyst Contacting Method.................... 16

EFFECT ON PYROLYSIS AND OTHER REACTIONS $\ldots \ldots \ldots \ldots \ldots \ldots \ldots \ldots \ldots, 16$

Tar and Light Hydrocarbon Yield........................ 16

Water-Gas Shift Reaction.............................. 18

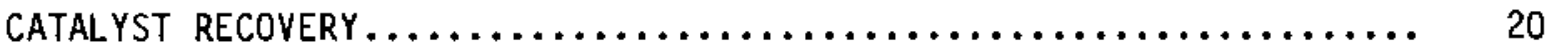

SECONDARY CATALYSTS $. \ldots \ldots \ldots \ldots \ldots \ldots \ldots \ldots \ldots \ldots \ldots \ldots \ldots \ldots \ldots \ldots \ldots \ldots \ldots, 23$

PRODUCTION OF SPECIFIC GASES $. \ldots \ldots \ldots \ldots \ldots \ldots \ldots \ldots \ldots \ldots \ldots \ldots, 23$

CATALYST LifETIME AND DEACTIVATION....................... 30

Catalyst Deactivation Studies......................... 31

Attrition.......................................... 39

MECHANISMS OF CATALYTIC GASIFICATION.......................... 41

PRIMARY CATALYSTS $. \ldots \ldots \ldots \ldots \ldots \ldots \ldots \ldots \ldots \ldots \ldots \ldots \ldots \ldots \ldots, 42$

Pyrolysis.......................................... 43

Gasification...................................... 44

Secondary Reactions $. \ldots \ldots \ldots \ldots \ldots \ldots \ldots \ldots \ldots \ldots \ldots \ldots, \quad 44$ 


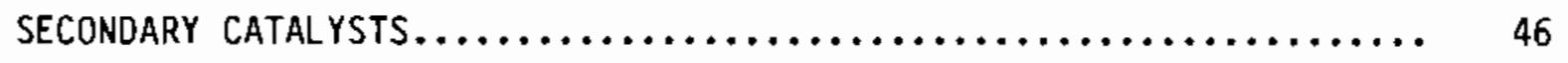

Catalytic Effects.................................. 46

Mechanisms of Carbon Deposition.................... 47

REFERENCES......................................... 55

APPENDIX A - GAS-PHASE REACTOR STUDIES WITH SECONDARY CATALYSTS........ A.1

APPENDIX $B$ - DATA FROM FIXED-BED LABORATORY TESTS................. B. 


\section{FIGURES}

1 Continuous-Feed Laboratory Reactor...................... 5

2 Gas-Phase Reactor.................................. 6

3 Catalytic Effect of $\mathrm{K}_{2} \mathrm{CO}_{3}$-Impregnated Wood as a Function of Catalyst Loading and Temperature....................... 15

4 Effect of Water/Residue Ratio on Potassium Recovery............. 20

5 Steam-Reforming of Phenol and Methane.................... 27

6 Effect of Metal Surface Area on Catalyst Lifetime at $550^{\circ} \mathrm{C} \ldots \ldots . \ldots 31$

7 Effect of Catalyst Age on Yield at $750^{\circ} \mathrm{C} \ldots \ldots \ldots \ldots \ldots \ldots \ldots \ldots \ldots$

8 Catalyst Deactivation in PDU with $\mathrm{Ni} / \mathrm{Al}_{2} \mathrm{O}_{3} \ldots \ldots \ldots \ldots \ldots \ldots \ldots \ldots \ldots$

9 Catalyst Deactivation in PDU with $\mathrm{NiCuMo} / \mathrm{SiO}_{2}-\mathrm{Al}_{2} \mathrm{O}_{3} \ldots \ldots \ldots \ldots$

10 Reaction Pathways for High-Temperature Steam Gasification of Biomass........................................ 42

11 SEM Micrograph of Catalyst Coked at $750^{\circ} \mathrm{C} \ldots \ldots \ldots \ldots \ldots \ldots \ldots \ldots \ldots$ 


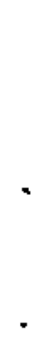




\section{TABLES}

1 Maximum Stoichiometric Yield of Specific Gas Products from the Reaction of Biomass with Steam.............................

2 Rate Constants for Catalyzed and Uncatalyzed Carbon/Steam Reaction.............................................. 12

3 Effect of $\mathrm{K}_{2} \mathrm{CO}_{3}$ at Various Temperatures....................... 13

4 Effect of $\mathrm{K}_{2} \mathrm{CO}_{3}$ on Various Feed Materials.................... 14

5 Comparison of $\mathrm{K}_{2} \mathrm{CO}_{3}$ and $\mathrm{Na}_{2} \mathrm{CO}_{3}$ at $3.0 \times 10^{-3}$ mole alkali/g wood........................................... 15

6 Effect of Alkali Carbonate Catalysts on Yields.................. 17

7 Effect of Potassium Carbonate on the Methane Yield in PDU Tests

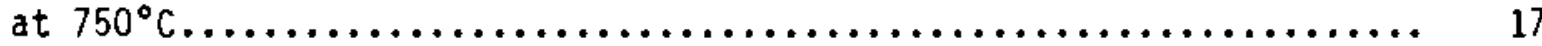

8 Effect of Alkali Carbonates on Methane Yield................... 18

9 Comparison of Alkali and Nickel Catalysts for the Water-Gas Shift Reaction in POU Tests............................ 18

10 Effect of Alkali on $\mathrm{H}_{2} / \mathrm{CO}$ Ratio in Laboratory Gasification Tests in a Continuous Reactór................................... 19

11 Secondary Reactions in Steam Gasification................... 24

12 Gas Compositions for Various Catalysts Tested for Synthesis Gas Production....................................... 25

13 Production of Specific Gases from Biomass by Steam Gasification..... 28

14 Typical Results of Various Catalytic Biomass Conversion Studies

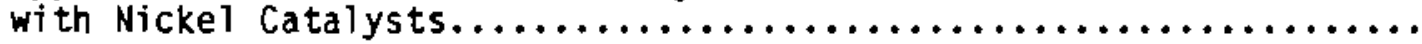

15 Catalytic Gasification with Various Metal 0xide Catalysts at

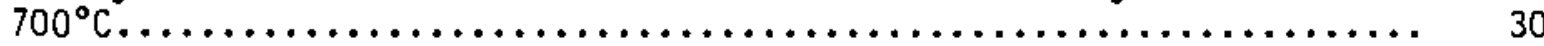

16 Carbon Deposition on Catalysts Used for Methanol Synthesis

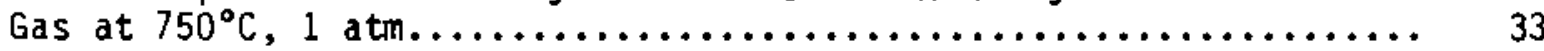

17 Effect of Steam Rate on Carbon Deposition with Phenol........... 34

18 Sulfur Analyses for Biomass Gasification................... 36

19 Effect of Sodium Carbonate on Carbon Conversion to Gas for Model Compounds Reacted with Steam at $600^{\circ} \mathrm{C} \ldots \ldots \ldots \ldots \ldots \ldots \ldots$ 
20 Different Types of Carbon Formation in Steam-Reforming of

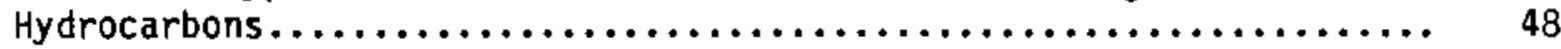

21 Effect of Feed on Carbon Deposition........................ 50

22 Effect of Catalyst Support on Carbon Deposition at $750^{\circ} \mathrm{C} \ldots \ldots \ldots \ldots$..... 51

A.1 Results of Fixed-Bed Gas-Phase Reactor Studies................. A.1

B.1 Results of Primary Catalyst Tests in Continuous Laboratory

Reactor............................................ B 


\section{INTRODUCTION}

In studies sponsored by the Biomass Energy Technology Division of the U.S. Department of Energy (DOE), the Pacific Northwest Laboratory (PNL) (a) has developed a catalytic steam gasification process that converts wood to specific product gases in one step using catalysts in the gasifier. This report summarizes the catalyst development studies performed in support of the PNL catalytic steam gasification process. (b) It also reviews state-of-the-art catalysis as it applies to gasification of biomass.

\section{BACKGROUND}

A variety of specific gas products can be produced by the reaction of biomass and steam, as shown in Table 1 . Without catalysts, however, gasification of biomass produces a wide variety of gases as well as char and tar by-products. The objective of PNL's catalytic biomass gasification program is to maximize production of specific gas products through the use of catalysts.

The yield of a specific gas from biomass may be limited by kinetics, thermodynamics, or both. High temperature alone will increase the yield of gases at the expense of by-product char and tar. However, this may be expensive and of ten has an adverse effect on the equilibrium concentration of the desired gas, thus reducing its yield.

The catalysts used in biomass gasification serve two primary functions: 1) to increase the yield of gases at the expense of tar and char at lower temperatures than are possible without catalysts, and 2) to catalyze secondary reactions to produce the specific product desired.

(a) Operated for the DOE by Battelle Memorial Institute.

(b) The PNL catalytic gasification studies were initiated late in 1977. Mudge et a 1. (1981) described the laboratory studies performed in 1978, 1979, and 1980 and the atmospheric-pressure process development unit (POU) tests of 1979 and 1980. Laboratory studies in 1981 and 1982 and the 1982 pressurized $(10 \mathrm{~atm})$ PDU tests are summarized by Mudge et al. (1983). Additional laboratory and POU tests conducted in 1983 with bagasse are described by Baker and Brown (1984). The results of laboratory studies in 1983 are also included in Appendices $A$ and $B$ of this report. 
TABLE 1. Maximum Stoichiometric Yield of Specific Gas Products from the Reaction of Biomass with Stearn

\begin{tabular}{|c|c|c|c|}
\hline & Gas Composition & $\begin{array}{l}\text { Yięld, } \\
\mathrm{nm}^{3} / \mathrm{kg} \\
\text { wood } \\
\end{array}$ & $\begin{array}{l}\text { Standard Heat } \\
\text { of Reaction, } \\
\mathrm{kJ} / \mathrm{kg} \text { wood }\end{array}$ \\
\hline \multicolumn{4}{|l|}{ Methane } \\
\hline $\mathrm{C}_{4} \mathrm{H}_{6} \mathrm{O}_{2.9}+1.1 \mathrm{H}_{2} \mathrm{O} \longrightarrow 2.0 \mathrm{CH}_{4}+2.0 \mathrm{CO}_{2}$ & $50 \% \mathrm{CH}_{4}, 50 \% \mathrm{CO}_{2}$ & 0.45 & -2010 \\
\hline \multicolumn{4}{|l|}{$\begin{array}{l}\text { Methanol or hydrocarbon } \\
\text { synthes is gas }\end{array}$} \\
\hline $\mathrm{C}_{4} \mathrm{H}_{6} \mathrm{O}_{2.9}+2.4 \mathrm{H}_{2} \mathrm{O}-5.4 \mathrm{H}_{2}+2.7 \mathrm{CO}+1.3 \mathrm{CO}_{2}$ & $\begin{array}{llll}57 \% & \mathrm{H}_{2}, 29 \% & \mathrm{CO}, \\
14 \% & \mathrm{CO}_{2}\end{array}$ & 1.8 & +3250 \\
\hline \multicolumn{4}{|l|}{ Hydrogen } \\
\hline $\mathrm{C}_{4} \mathrm{H}_{6} \mathrm{O}_{2.9}+5.1 \mathrm{H}_{2} \mathrm{O} \longrightarrow 8.1 \mathrm{H}_{2}+4 \mathrm{CO}_{2}$ & $67 \% \mathrm{H}_{2}, 33 \% \mathrm{CO}_{2}$ & 1.8 & +3280 \\
\hline \multicolumn{4}{|l|}{ Ammonia synthesis gas } \\
\hline $\mathrm{C}_{4} \mathrm{H}_{6} \mathrm{O}_{2.9}+4.0 \mathrm{H}_{2} \mathrm{O}-2.3 \mathrm{~N}_{2}+4 \mathrm{CO}_{2}$ & 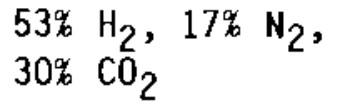 & 2.1 & -120 \\
\hline
\end{tabular}


Two types of catalysts have been studied. Primary catalysts, usually a]kali carbonates, are doped on or mixed with the biomass. They are well-known catalysts for the carbon/steam reaction, and have also been found to have a significant effect on biomass pyrolysis. Secondary catalysts--nickel or other transition metals on supports such as alumina or silica-alumina--are used to catalyze secondary gas phase reactions such as steam-reforming, methanation, and the water-gas shift reaction.

Two terms that will be used throughout this report are catalyst loading and catalyst 1 ifetime. Catalyst loading refers to the mass of primary catalyst doped on the biomass feedstock per unit mass of biomass and is given in wto or in moles of metal ion per unit mass of biomass. Catalyst lifetime is associated with secondary catalysts, and is the mass of biomass fed to the gasifier per unit mass of catalyst in the gasifier before the catalyst shows a serious loss of activity. In all of the gasifier systems, biomass is fed to the reactor at approximately one mass unit of biomass per mass unit of catalyst per hour. Catalyst lifetime is therefore also approximately equal to the number of hours onstream before deactivation, as shown below:

$$
\frac{\text { wt biomass gasified }}{\text { we catalyst in gasifier }} \times \frac{\text { wt catalyst in gasifier } \cdot \text { hour }}{\text { wt biomass }}=\text { hours }
$$

$$
\text { (1ifetime) (feed ratio) }
$$

Laboratory tests have shown that a feed ratio of one provides sufficient residence for secondary reactions to reach equilibrium.

\section{EXPERIMENTAL FACILITIES}

The catalytic gasification studies at PNL were conducted primarily in laboratory-scale reactors operated at atmospheric pressure and at temperatures ranging from 550 to $850^{\circ} \mathrm{C}$. A batch feed reactor was used in the primary catalyst studies to obtain kinetic data (Mudge, Sealock, and Weber 1979; Mudge et a1. 1981). Wood samples 5 to $15 \mathrm{~g}$ in size were charged to the preheated reactor. The evolution of gases was measured over time to determine the rate of gasification. Two continuous-wood-feed reactors were designed to screen secondary catalysts (Mudge et al. 1981, 1983). Wood was fed at a rate of 8 to $12 \mathrm{~g} / \mathrm{h}$ into the top of reactor, where it pyrolyzed. The pyrolysis products 
passed over a fixed bed of catalyst $(10$ to $20 \mathrm{~g})$. Char that accumulated on top of the catalyst bed was vacuumed out periodicaliy.

To study primary catalysts in a continuous reactor, one of the reactors used for secondary catalyst studies was modified to provide continuous char removal, as shown in Figure 1. By adjusting the speed of the rotating grate, the rate of char removal could be controlled, allowing operation at varying residence times.

A fixed-bed gas-phase reactor (shown in Figure 2) was built to study carbon deposition on secondary catalysts using model compounds. Feed materials passed through a preheating zone and then over a bed of catalyst (5 to $10 \mathrm{~g})$.

Many of the results obtained in the laboratory gasifiers have been verified in a 1-ton/day PDU. The PDU is a fluidized-bed gasifier that has been operated at 100 to $1000 \mathrm{kPa}$ and 500 to $750^{\circ} \mathrm{C}$. A description of the facility and operations at atmospheric pressure (Mudge et a1. 1981; Mitchell et al. 1980) and at 10 atmospheres (Mudge et al. 1983; Baker et a 1. 1983) have been given previously.

Wood has been the primary feedstock for both laboratory and PDU tests. Other materials used in laboratory tests have included bagasse, rice straw, alfalfa, and almond hulls. Bagasse has also been tested in the PDU. Proximate and ultimate analyses, and the heating value of these materials, are given by Mudge et a1. (1983) and Baker and Brown (1984).

Catalysts used in the PNL studies were of the following origins:

- commercially available (primarily Harshaw and United Catalysts)

- prepared for PNL by W. R. Grace, Inc.

- prepared at PNL, either by metal impregnation on commercial supports or by coprecipation.

The analytical methods were basically the same for all of the gasifier systems. The product stream from the gasifier was cooled and the liquids condensed and separated. Gas flow was measured and the gas was analyzed with a Carle AGC-S gas chromatograph. Gas analysis included $\mathrm{H}_{2}, \mathrm{CO}, \mathrm{CO}_{2}$, and hydrocarbon gases $C_{1}$ through $C_{4}$. Tars were collected and weighed and then analyzed with a Perkin-Elmer 240 elemental analyzer. A Dohmann DC-80 carbon analyzer 


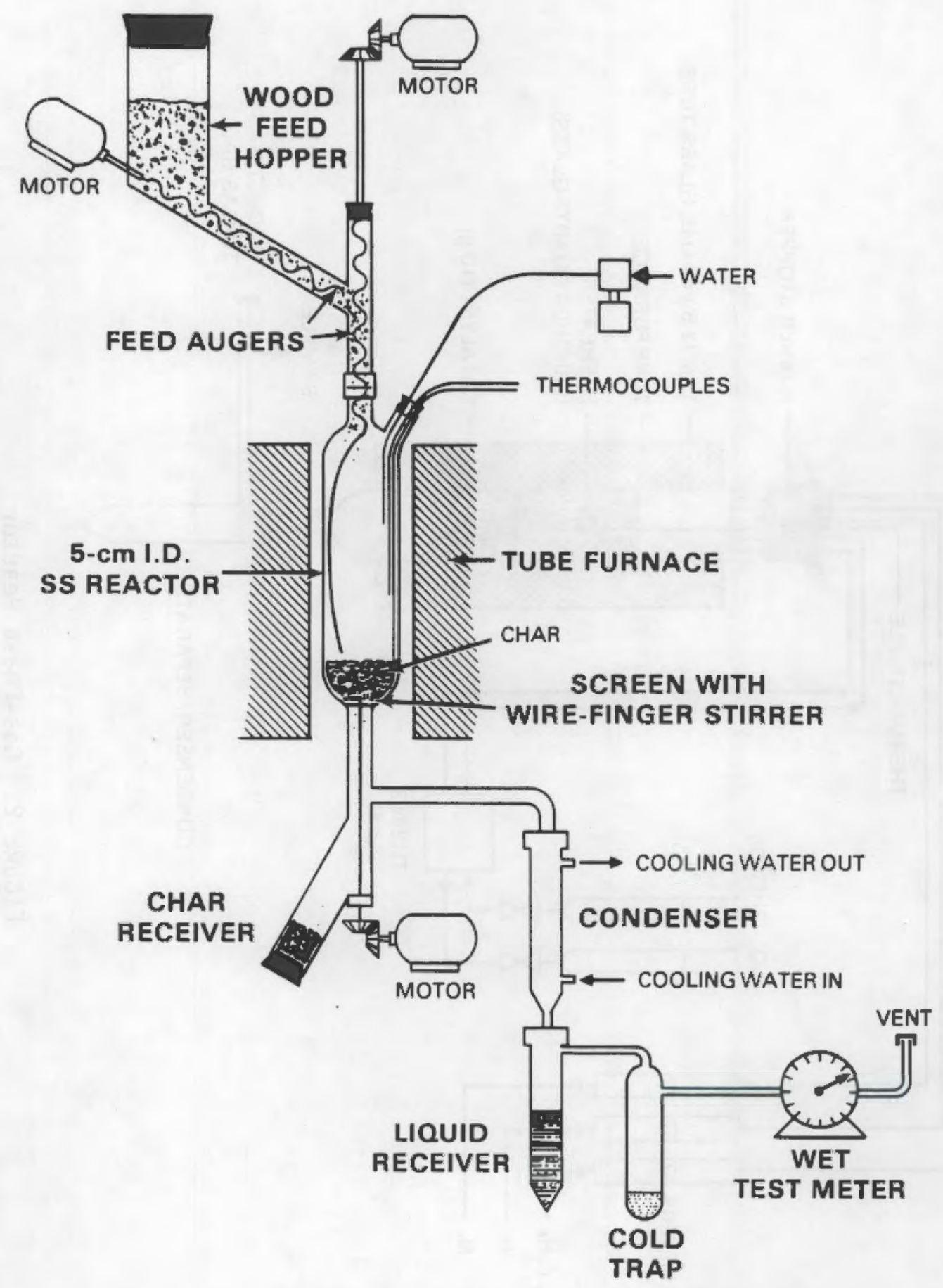

FIGURE 1. Continuous-Feed Laboratory Reactor 


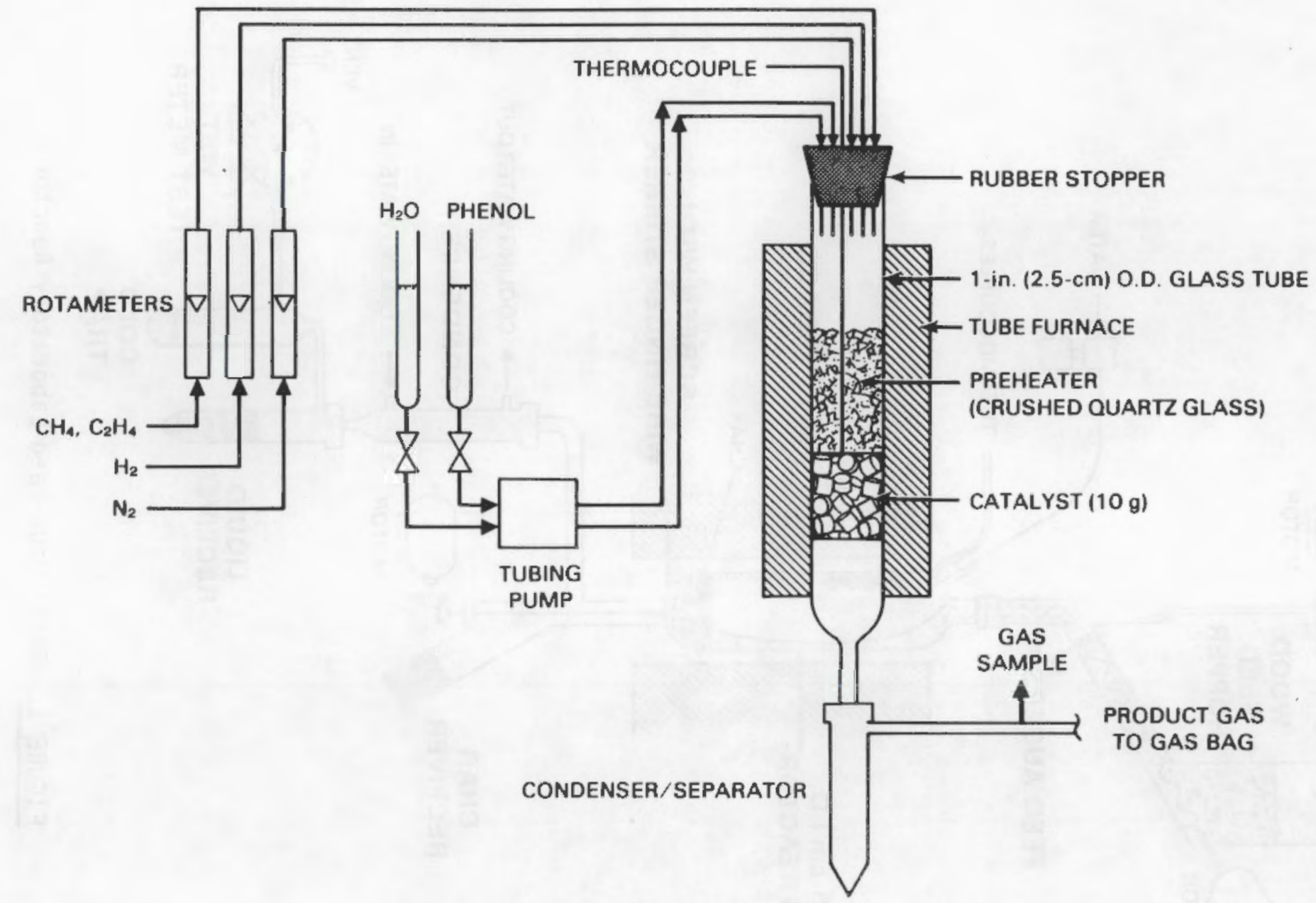

FIGURE 2. Gas-Phase Reactor 
was used to determine the water-soluble organics content of the condensate. Char was collected and weighed, and its elemental content was determined. Sulfur analyses were performed on a limited number of feedstocks and product gases. 


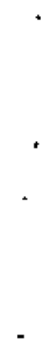




\section{CONCLUSIONS AND RECOMMENDATIONS}

This study has examined the effects of two types of catalysts on hightemperature steam gasification of biomass. Primary catalysts (alkali carbonates) alter pyrolysis reaction pathways and catalyze various secondary reactions, significantly altering the final product distribution. Some insights have been gained on the effect of alkali carbonates on pyrolysis and secondary reactions, but a better understanding of the mechanisms involved would lead to more effjcient use of these catalysts. Alkali carbonates do catalyze the reaction of biomass char with steam, but they have little net effect on char yield in the fluidized-bed PDU. The physical characteristics of the gasifier, residence time, superficial gas velocity, and the particle size of the biomass appear to have a much larger effect on overall conversion than do primary catalysts. This will be studied in more detail in the bench-scale fluidized bed.

Supported-nickel catalysts are the most effective catalysts for maximizing production of specific gases. With an active catalyst, equilibrium gas-phase compositions are achieved and all liquid products are converted to gases. At $550^{\circ} \mathrm{C}$ and low steam rates a methane-rich gas is produced; at $750^{\circ} \mathrm{C}$ and somewhat higher steam rates a high-quality synthesis gas or hydrogen-rich gas is produced.

Unfortunately, nickel catalysts are subject to deactivation. Deactivation can be caused by coking (carbon deposition), sintering, or sulfur poisoning. With wood, coking was found to be the major cause of deactivation. At $550^{\circ} \mathrm{C}$ carbon deposition was quite severe and all catalysts tested rapidly lost their activity. At $750^{\circ} \mathrm{C}$ in the laboratory gasifiers (where the catalyst is physically separated from biomass during pyrolysis) carbon deposition was less severe and several catalysts were found to maintain much of their original activity for an extended period of time. Coking in the laboratory gasifier at $750^{\circ} \mathrm{C}$ was the result of pyrolysis and cracking of tars and light hydrocarbons on the catalyst support. At $550^{\circ} \mathrm{C}$ other types of carbon deposition such as whisker formation may occur. This type of coking is more rapid and results in larger carbon accumulations. It is also possible that a different mechanism 
for coking is involved in the PDU, where the catalyst is intimately mixed with biomass during pyrolysis.

As part of the bench-scale fluidized-bed testing now in progress, the mechanism by which carbon deposition occurs when the catalyst is intimately mixed with biomass during pyrolysis will be investigated at both $750^{\circ} \mathrm{C}$ and $550^{\circ} \mathrm{C}$. An understanding of the coking mechanism will facilitate the choice of catalyst and operating conditions to reduce coking. 
PRIMARY CATALYSTS

The application of alkali catalysts to coal gasification has long been known (Taylor 1921) and has been studied extensively in recent years. (a) The primary effect of these catalysts in coal gasification is to increase the rate of the reaction of char with steam and carbon dioxide:

$$
\begin{aligned}
& \mathrm{C}+\mathrm{H}_{2} \mathrm{O} \rightarrow \mathrm{CO}+\mathrm{H}_{2} \\
& \mathrm{C}+\mathrm{CO}_{2} \rightarrow 2 \mathrm{CO}
\end{aligned}
$$

Alka1i catalysts have also been studied in relation to biomass. (b) However, because of the high reactivity of biomass (a large portion of the carbon can be volatilized at relatively low temperatures), the overall effect of aikali catalysts is more difficult to evaluate.

When biomass is contacted with steam at elevated temperatures, a series of complex physical changes and chemical reactions are initiated. A simplified model describes the gasification process in two stages: 1) rapid volatilization to yield gases, condensible liquids, and char; followed by 2) secondary reactions of steam with the char and pyrolysis products. Studies at PNL have shown that alkali catalysts have a significant effect on both stages of gasification. The overall effect is a combination of the two and must be evaluated as such. For example, the Exxon catalytic coal gasification (CCG) process uses $\mathrm{K}_{2} \mathrm{CO}_{3}$ to catalyze the steam/char reaction. To reach $90 \%$ carbon conversion to gas, the residence time in the CCG gasifier with the catalyst is 6 to $10 \mathrm{~h}$ at $700^{\circ} \mathrm{C}$ (Nahas 1983). In contrast, with biomass, high carbon conversion to volatiles can be achieved at 550 to $750^{\circ} \mathrm{C}$ without catalysts and with residence times of less than one hour. The effect of alkali catalysts on the yields of specific products from pyrolysis becomes much more important for biomass than for coal.

(a) Haynes, Gasior, and Forney 1974; Willson et al. 1974; Veraa and Bell 1978; McKee et al. 1983; Walker et al. 1983; McCoy 1983; Nahas 1983.

(b) Mudge, Sealock, and Weber 1979; Mudge et al. 1981; Sealock, E1liott, and Hallen 1982; Hawley et al. 1983; Ross and Fong 1981; Tran and Raj 1978. 
CARBON/STEAM REACTION

To evaluate the effect of alkali on the carbon/steam reaction, samples of wood were gasified in a batch reactor with flowing steam. Temperatures from 550 to $850^{\circ} \mathrm{C}$ were studied with different catalyst systems. Carbon conversion to gas was measured as a function of time. The percentage of carbon remaining was defined as the difference between the carbon charged to the reactor and the carbon in the gas. Assuming pseudo-first-order-reaction kinetics, the carbon/ steam reaction rate constant can be expressed as:

$$
k=\frac{1}{t_{2}-t_{1}} \ln \left(\frac{c_{1}}{c_{2}}\right)
$$

where $C_{1}$ is the carbon remaining at time $t_{1}$, and $C_{2}$ is the carbon remaining at time $t_{2}$.

Following the rapid-rate pyrolysis period, a plot of the log of the remaining carbon versus time is generally linear, confinming first-order kinetics (Mudge, Sealock, and Weber 1979; Mudge et al. 1981). The slope of the line is the rate constant for the carbon/steam reaction. Table 2 shows rate constants for Douglas fir at $550^{\circ} \mathrm{C}, 650^{\circ} \mathrm{C}$, and $750^{\circ} \mathrm{C}$ with $17 \mathrm{wto}_{2} \mathrm{CO}_{3}$. Similar results have been obtained by Sealock et al. (1981) and Sealock, Elliott, and Hallen (1982).

Table 3 presents the ratio of catalyzed to uncatalyzed rates for several different investigations. The effect is small at $550^{\circ} \mathrm{C}$ but increases at $650^{\circ} \mathrm{C}$

TABLE 2. Rate Constants for Catalyzed and Uncatalyzed Carbon/Steam Reaction

\begin{tabular}{cccc}
$\begin{array}{c}\text { Temperature, } \\
{ }^{\circ} \mathrm{C}\end{array}$ & $\begin{array}{c}\text { wt\% } \\
\text { Catalyst }\end{array}$ & & $\begin{array}{c}\text { Rate Constant, } \\
\mathrm{s}^{-1}\end{array}$ \\
\cline { 1 - 2 } 550 & 17 & & $1.4 \times 10^{-4}$ \\
550 & - & $1.1 \times 10^{-4}$ \\
650 & 17 & $3.4 \times 10^{-4}$ \\
650 & 0 & $9.6 \times 10^{-5}$ \\
750 & 17 & $9.9 \times 10^{-4}$ \\
750 & 0 & $2.0 \times 10^{-4}$
\end{tabular}

Ratio of Catalyzed to Uncatalyzed

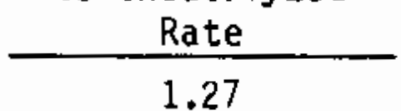

1.27

3.5

4.9 
TABLE 3. Effect of $\mathrm{K}_{2} \mathrm{CO}_{3}$ at Various Temperatures

Ratio of Catalyzed Rate to Uncatalyzed Rate

Oouglas Fir(a) Douglas Fir (b) Jack Pine Bark Char (c)

Temperature, ${ }^{\circ} \mathrm{C}$

550 and $17 \mathrm{wt} \% \mathrm{~K}_{2} \mathrm{CO}_{3}$ and $8 \mathrm{wt}_{\mathrm{H}} \mathrm{K}_{2} \mathrm{CO}_{3}$

650

1.3

2.6

1.0

750

3.5

5.4

2.3

850

4.9

4.7

3.5

(a) Data from Mudge et al. (1981).

(b) Data from Sealock, Elliott, and Hallen (1982).

(c) Oata from Ross and Fong (1981).

and $750^{\circ} \mathrm{C}$, and may fall of at higher temperatures. Ross and Fong (1981) found that $5 \mathrm{wto} \mathrm{K}_{2} \mathrm{CO}_{3}$ reduced the gasification rate of jack pine bark char at temperatures below $550^{\circ} \mathrm{C}$.

Mckee et al. (1983) have studied the relationship between the magnitude of the catalytic effect produced by alkali metal salts and coal rank. These results are compared in Table 4 to those obtained at PNL with biomass. Char from lignite was the most reactive char tested, and the addition of $10 \mathrm{wt} \%$ $\mathrm{K}_{2} \mathrm{CO}_{3}$ increased the reactivity about fourfold. Graphite char was the least reactive, but the effect of adding alkali was quite large. Winter, Malcosky, and Hong (1982) observed a similar effect with $\mathrm{Na}_{2} \mathrm{CO}_{3}$ and a bituminous coal, a subbituminous coal, and a lignite. Biomass falls near the lignite end of the scale, as might be expected due to its high reactivity.

Rate constants obtained at various temperatures were used to calculate the activation energies of the carbon/steam reaction for wood. The activation energy, $E_{a}$, is obtained from a plot of $1 n k$ versus $1 / T$. The activation energy is proportional to the slope as dictated by the Arrhenius equation:

$$
\ln \frac{k_{2}}{k_{1}}=\frac{E_{a}}{R}\left(\frac{T_{2}-T_{1}}{\overline{T_{1} T_{2}}}\right)
$$


TABLE 4. Effect of $\mathrm{K}_{2} \mathrm{CO}_{3}$ on Various Feed Materials

\begin{tabular}{|c|c|c|c|}
\hline & ${ }^{\circ} \mathrm{C}$ & $\mathrm{wt}_{\mathrm{N}} \mathrm{K}_{2} \mathrm{CO}_{3}$ & Uncatalyzed Rate \\
\hline Biomass $(a)$ & 750 & 17 & 4.9 \\
\hline Lignite & 700 & 10 & 3.8 \\
\hline Subbituminous coal & 700 & 10 & 7.5 \\
\hline Bituminous coal, hva & 800 & 10 & 11 \\
\hline Bituminous coal, hvB & 700 & 10 & 16 \\
\hline Anthracite & 800 & 10 & 25 \\
\hline Graphite & 900 & 10 & 470 \\
\hline
\end{tabular}

(a) Data from Mudge et al. (1981).

where $k_{1}$ is the rate constant at $T_{1}, k_{2}$ is the rate constant at $T_{2}$, and $R$ is the gas constant. The sensitivity of the carbon/steam reaction to changes in temperature is reflected by the activation energies.

Activation energies determined at PNL for the carbon/steam reaction with wood ranged from 92 to $125 \mathrm{~kJ} / \mathrm{mole}$ for uncatalyzed wood and from 71 to $125 \mathrm{~kJ} /$ mole when alkali catalysts were used (Mudge et al. 1981; Sealock et al. 1981). In general, the activation energies were somewhat lower in the presence of catalysts, but the difference was not large.

Effect of Catalyst Type

Three catalysts have been studied extensively at PNL: $\mathrm{K}_{2} \mathrm{CO}_{3}, \mathrm{Na}_{2} \mathrm{CO}_{3}$, and $\mathrm{Cs}_{2} \mathrm{CO}_{3}$. Table 5 shows that $\mathrm{K}_{2} \mathrm{CO}_{3}$ and $\mathrm{Na}_{2} \mathrm{CO}_{3}$ have nearly the same catalytic effect on the carbon/steam reaction. Sealock, Elliott, and Hallen (1982) also found $\mathrm{K}_{2} \mathrm{CO}_{3}$ and $\mathrm{Na}_{2} \mathrm{CO}_{3}$ to be similar in their catalytic effect on Douglas fir gasification. They found $\mathrm{Cs}_{2} \mathrm{CO}_{3}$ to be slightly more effective.

Effect of Catalyst Loading

Figure 3 shows the relationship between catalyst loading and catalytic effect for $\mathrm{K}_{2} \mathrm{CO}_{3}$-impregnated wood. At $650^{\circ} \mathrm{C}$ and $750^{\circ} \mathrm{C}$ catalyst effectiveness increased with increased loading up to $12 \mathrm{wt} \%\left(2.25 \times 10^{-3}\right.$ mole alkali/g wood $)$. At $17 \mathrm{wt} \%$ the effectiveness was about equal to that at $12 \mathrm{wt} \%\left(750^{\circ} \mathrm{C}\right)$ or somewhat reduced $\left(650^{\circ} \mathrm{C}\right)$. At $550^{\circ} \mathrm{C}$ the char/steam reaction is quite slow and the effect of the catalyst is quite small. 
TABLE 5. Comparison of $\mathrm{K}_{2} \mathrm{CO}_{3}$ and $\mathrm{Na}_{2} \mathrm{CO}_{3}$ at $3.0 \times 10^{-3}$ mole alkali/g wood Catalyzed Rate/Uncatalyzed Rate

\begin{tabular}{|c|c|c|}
\hline Temperature, ${ }^{\circ} \mathrm{C}$ & $\mathrm{K}_{2} \mathrm{CO}_{3}$ & $\mathrm{Na}_{2} \mathrm{CO}_{3}$ \\
\hline 550 & 1.3 & 1.2 \\
\hline 650 & 3.5 & 3.5 \\
\hline 750 & 4.8 & 4.3 \\
\hline
\end{tabular}

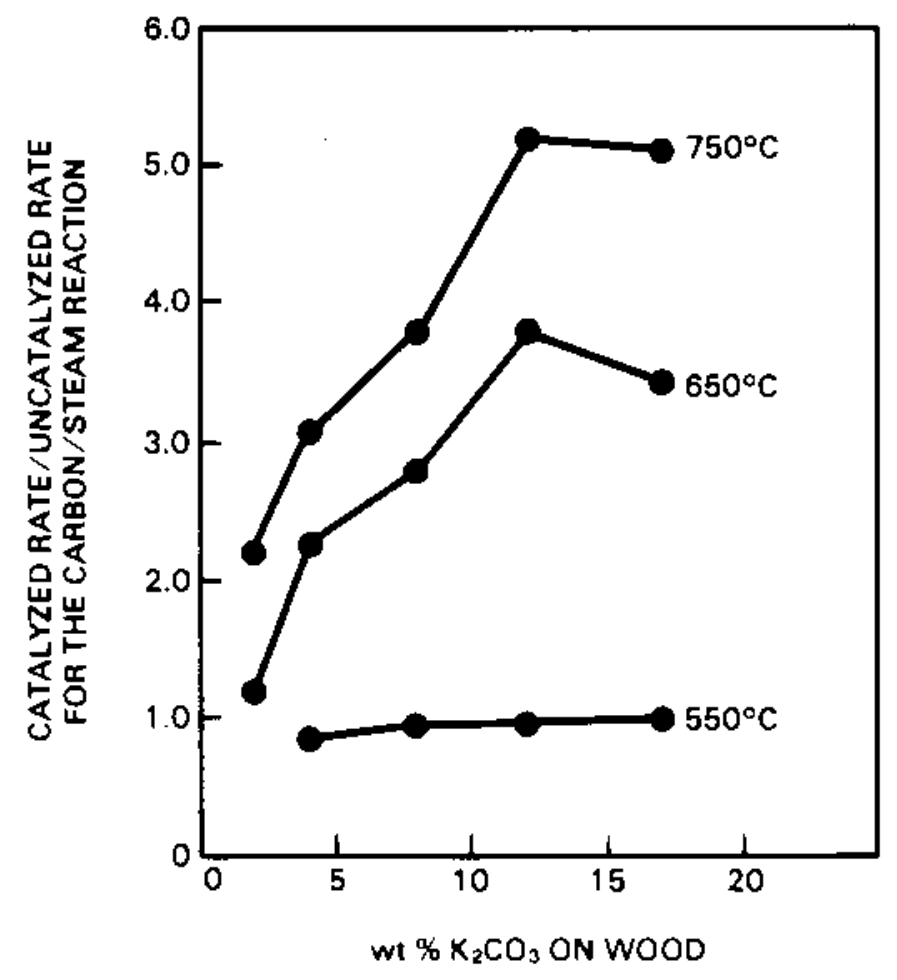

FIGURE 3. Catalytic Effect of $\mathrm{K}_{2} \mathrm{CO}_{3}$-Impregnated Wood as a Function of Catalyst Loading and Temperature

In the continuous reactor, increased loadings (up to $3 \times 10^{-3}$ mole alkali/g wood) increased effectiveness at short residence times. However, at longer residence times and high conversions, high loadings reduced the rate of char gasification. Diffusion through the ash layer may limit the gasification rate under these conditions. 
Effect of Catalyst Contacting Method

Previous PNL laboratory studies concluded that impregnation was a more effective means of adding catalyst than dry-mixing, although a significant catalytic effect was still achieved by dry-mixing the catalyst (Mudge et al. 1981). Sealock, Elliott, and Hallen (1982) concluded that there was little difference between impregnation and dry-mixing. Tests in the fluidized-bed PDU showed $\mathrm{Na}_{2} \mathrm{CO}_{3}$ to be almost totally ineffective when physically mixed with wet wood chips. Tests with $\mathrm{K}_{2} \mathrm{CO}_{3}$ mixed with wet wood chips were much more successful. The higher solubility of $\mathrm{K}_{2} \mathrm{CO}_{3}$ enabled it to absorb into the wet wood chips almost entirely, while the $\mathrm{Na}_{2} \mathrm{CO}_{3}$ remained primarily a solid when mixed with the wood chips. The lack of effectiveness of $\mathrm{Na}_{2} \mathrm{CO}_{3}$ dry-mixed at the POU is not understood at this time.

\section{EFFECT ON PYROLYSIS AND OTHER REACTIONS}

The effect of alkali catalysts on the pyrolysis of biomass is not as well known as their effect on the gasification of the char residue. However, because biomass has much more volatile carbon than fixed carbon, the effect of alkali on the pyrolysis reactions of biomass becomes more important than on those of coal. PNL studies have shown that at 550 to $750^{\circ} \mathrm{C}$ and atmospheric pressure, alkali catalysts reduce or eliminate tars, oils, and soluble organics, reduce the yield of methane and other light hydrocarbons, and catalyze the water-gas shift reaction.

Tar and Light Hydrocarbon Yield

The effect of alkali on the yield of tars and light hydrocarbon gases at $750^{\circ} \mathrm{C}$ is shown in Table 6 . These data are from the continuous-feed reactor system. With no catalyst the yield of tar and condensible organics was $11 \%$ (weight of original carbon present as condensible organics). With various alkali metal salt catalysts almost no tar was detected. Analysis of the condensate showed that almost no soluble organic material was present.

There was some reduction in the amount of methane and other light hydrocarbon gases in the continuous laboratory gasifier (Table 6). The effect of alkali on methane yield is more dramatic in POU tests (Table 7). Veraa and 
TABLE 6. Effect of Alkali Carbonate Catalysts on Yields

$\left(750^{\circ} \mathrm{C}\right.$, residence time $\left.\sim 20 \mathrm{~min}\right)$

\begin{tabular}{l} 
Product Yield from \\
Carbon Conversion \\
\hline
\end{tabular}

Synthesis gas $\left(\mathrm{CO}, \mathrm{CO}_{2}, \mathrm{H}_{2}\right)$

$\mathrm{CH}_{4}$

$\mathrm{C}_{2} \mathrm{H}_{6}, \mathrm{C}_{2} \mathrm{H}_{4}$ Total gas

Tar

Water-soluble organics

Char
Percent of Total Carbon in Wood Converted

\begin{tabular}{|c|c|c|c|c|}
\hline $\begin{array}{l}13 \mathrm{wt}_{\%} \\
\mathrm{Na}_{2} \mathrm{CO}_{3}\end{array}$ & $\begin{array}{r}8.5 \mathrm{wt}_{\mathrm{O}} \\
\mathrm{K}_{2} \mathrm{CO}_{3} \\
\end{array}$ & $\begin{array}{l}6.5 \mathrm{wt} \% \\
\mathrm{Na}_{2} \mathrm{CO}_{3} \\
\end{array}$ & $\begin{array}{l}17 \mathrm{wt}^{\circ} \\
\mathrm{K}_{2} \mathrm{CO}_{3}\end{array}$ & Uncatalyzed \\
\hline 53 & 57 & 58 & 60 & 42 \\
\hline 8 & 7 & 9 & 8 & 10 \\
\hline 5 & 4 & 4 & 5 & 5 \\
\hline 66 & 68 & 71. & 73 & 57 \\
\hline $\operatorname{tr}(a)$ & tr & $\operatorname{tr}$ & tr & 8 \\
\hline tr & $\operatorname{tr}$ & $\operatorname{tr}$ & tr & 3 \\
\hline 34 & 31 & 28 & 27 & 32 \\
\hline
\end{tabular}

(a) $\operatorname{tr}=$ trace quantity, probably less than $0.1 \%$.

TABLE 7. Effect of Potassium Carbonate on the Methane Yield in PDU Tests at $750^{\circ} \mathrm{C}$

\begin{tabular}{lcc} 
& $\mathrm{CH}_{4}$ Yield, $\mathrm{nm}^{3} / \mathrm{kg}$ dry wood \\
\cline { 2 - 3 } & $\frac{1 \mathrm{~atm}}{0.133}$ & $\frac{10 \mathrm{~atm}}{0.182}$ \\
Uncatalyzed & 0.045 & 0.108 \\
Catalyzed $\left(\mathrm{K}_{2} \mathrm{CO}_{3}\right)$ & 0.004 & 0.098
\end{tabular}

(a) Gas phase equilibrium assuming $80 \%$ carbon conversion to gas.

Bell (1978) also noted that high loadings of $\mathrm{K}_{2} \mathrm{CO}_{3}$ suppressed formation of methane during gasification of coal at atmospheric pressure and at temperatures ranging from 700 to $900^{\circ} \mathrm{C}$.

The overall effect of the decreased yield of tar and methane is a significant increase in yield of hydrogen and carbon monoxide (synthesis gas).

Exxon found that $\mathrm{K}_{2} \mathrm{CO}_{3}$ mixed with coal char increased methane yield at temperatures of $700^{\circ} \mathrm{C}$ or more and elevated pressure. The methanation reaction was essentially brought to equilibrium (Nahas 1983). In other PNL studies, Sealock, Elliott, and Hallen (1982) found that at atmospheric pressure 17 wt\% $\mathrm{K}_{2} \mathrm{CO}_{3}$ had 7 ittle effect on methane yield at $550^{\circ} \mathrm{C}$ and $650^{\circ} \mathrm{C}$ but decreased the 
yield by almost $50 \%$ at $750^{\circ} \mathrm{C}$ (Table 8 ). At $1000 \mathrm{kPa}$ the effect of $\mathrm{K}_{2} \mathrm{CO}_{3}$ on $\mathrm{CH}_{4}$ yield was smaller. With 13 wto $\mathrm{Na}_{2} \mathrm{CO}_{3}$ the yield of methane was significantly increased at all three temperatures and atmospheric pressure. At pressure $\mathrm{Na}_{2} \mathrm{CO}_{3}$ had little effect on the methane yield.

The effect of alkali carbonates on methane yield appears to vary significantly depending on the conditions (Table 8 ). Residence time may play an important part and should be investigated further.

Water-Gas Shift Reaction

Alkali carbonates impregnated on wood significantly affect the $\mathrm{H}_{2} / \mathrm{CO}$ ratio of the gas produced by gasification. This can be seen in the PDU (Table 9)

TABLE 8. Effect of Alkali Carbonates on Methane Yield $\left(\mathrm{nm}^{3} / \mathrm{kg}\right.$ dry wood) (a)

\begin{tabular}{|c|c|c|c|c|}
\hline & \multicolumn{2}{|c|}{$550^{\circ} \mathrm{C}$} & \multicolumn{2}{|c|}{$750^{\circ} \mathrm{C}$} \\
\hline & $1 \mathrm{~atm}$ & $10 \mathrm{~atm}$ & $1 \mathrm{~atm}$ & $10 \mathrm{~atm}$ \\
\hline Uncatalyzed & 0.015 & 0.071 & 0.058 & 0.122 \\
\hline $17 \mathrm{wt} \% \mathrm{~K}_{2} \mathrm{CO}_{3}$ & 0.021 & 0.053 & 0.032 & 0.106 \\
\hline $13 \mathrm{wt}^{2} \mathrm{Na}_{2} \mathrm{CO}_{3}$ & 0.027 & 0.046 & 0.070 & 0.103 \\
\hline
\end{tabular}

(a) Data from Sealock, Elliott, and Hallen (1982).

TABLE 9. Comparison of Alkali and Nickel Catalysts for the Water-Gas Shift Reaction in PDU Tests

\begin{tabular}{|c|c|c|c|}
\hline & \multicolumn{3}{|c|}{ Catalyst } \\
\hline & $10 \mathrm{wt}^{2} \mathrm{~K}_{2} \mathrm{CO}_{3}$ & Ni/Alumina & None \\
\hline Steam rate, $\mathrm{kg} / \mathrm{kg}$ dry bagasse & 0.95 & 1.0 & 1.1 \\
\hline \multicolumn{4}{|l|}{ Gas composition } \\
\hline $\mathrm{H}_{2}$ & 55 & 57 & 36 \\
\hline $\mathrm{CO}_{2}$ & 24 & 20 & 23 \\
\hline $\mathrm{CH}_{4}$ & 4 & 2 & 13 \\
\hline CO & 11 & 21 & 26 \\
\hline$c_{2}$ and $c_{3}$ & 1 & $\operatorname{tr}$ & 2 \\
\hline $\mathrm{H}_{2} / \mathrm{CO}$ ratio & 5.0 & 2.8 & 1.4 \\
\hline
\end{tabular}


where the $\mathrm{H}_{2} / \mathrm{CO}$ ratio was 5.0 for the catalyzed case compared to 1.4 with no catalyst, and in laboratory tests (Table 10) where it increased from 2.1 to 3.4 when $\mathrm{K}_{2} \mathrm{CO}_{3}$ was used. In both cases all other conditions were nearly the same. Sealock, Elliott, and Hallen (1982) also found that alkali affected the $\mathrm{H}_{2} / \mathrm{CO}$ ratio in biomass gasification tests. To check the catalytic effect, $\mathrm{CO}$ and $\mathrm{H}_{2} \mathrm{O}$ were passed over $\mathrm{Na}_{2} \mathrm{CO}_{3}$ at $600^{\circ} \mathrm{C}$ and $\mathrm{H}_{2}$ and $\mathrm{CO}_{2}$ were produced. Without a catalyst, little or no shift was detected.

In PDU tests with bagasse $\mathrm{K}_{2} \mathrm{CO}_{3}$ was apparently a more effective shift catalyst than were nickel catalysts, as shown in Table 9 . In fact the $\mathrm{H}_{2} / \mathrm{CO}$ ratio is higher than the calculated equilibrium ratio at $750^{\circ} \mathrm{C}$ and 1 atmosphere. One possible explanation for the high $\mathrm{H}_{2} / \mathrm{CO}$ rate with alkali in the PDU is that the gas continues to react with the alkali-impregnated char that is carried out of the gasifier. At the lower temperatures in the off-gas system a $\mathrm{H}_{2} / \mathrm{CO}$ ratio higher than the equilibrium value at $750^{\circ} \mathrm{C}$ could be attained. Gas samples are taken after the char has been removed in a filter vessel (which operates at about $300^{\circ} \mathrm{C}$ ) and may show a higher $\mathrm{H}_{2} / \mathrm{CO}$ ratio than is actually produced in the gasifier. TABLE 10. Effect of Alkali on $\mathrm{H}_{2} / \mathrm{CO}$ Ratjo in Laboratory Gasification
Tests in a Continuous Reactor

\begin{tabular}{lcr} 
& \multicolumn{2}{c}{ Catalyst } \\
\cline { 2 - 3 } Gas composition, vo1\% & 52.4 & 39.0 \\
$\mathrm{H}_{2}$ & 25.3 & 28.8 \\
$\mathrm{CO}_{2}$ & 5.4 & 10.9 \\
$\mathrm{CH}_{4}$ & 15.2 & 18.1 \\
$\mathrm{CO}$ & 1.6 & 3.3 \\
$\mathrm{C}_{2}$ & 3.4 & 2.1 \\
$\mathrm{H}_{2} / \mathrm{CO}$ ratio & &
\end{tabular}

(a) $750^{\circ} \mathrm{C}, 1 \mathrm{~atm}, \mathrm{H}_{2} \mathrm{O} /$ wood $=1$, residence time $\sim 15 \mathrm{~min}$. 
CATALYST RECOVERY

The cost of alkali metal catalysts and the loadings required necessitates the recovery of the catalyst from the gasification residue (char, ash, catalyst). Catalyst recovery tests were performed on residue from laboratory gasification tests with both wood and bagasse (Mudge et a1. 1981; Baker and Brown 1984). The wood residue contained about 50\% char and 50\% ash which was almost entirely from the $\mathrm{K}_{2} \mathrm{CO}_{3}$ doped on the wood. With a water wash of $10 \mathrm{ml} / \mathrm{g}$ residue, about $95 \%$ of the potassium was recovered; with $100 \mathrm{ml} / \mathrm{g}$ of residue, about $98 \%$ was recovered.

The bagasse residue generally contained about $40 \%$ char and $60 \%$ ash. About $30 \%$ of the ash was from the bagasse, the remainder from the $\mathrm{K}_{2} \mathrm{CO}_{3}$ doped on the bagasse. Figure 4 shows the effect of water/residue ratio on potassium recovery. About $80 \%$ recovery was obtained with as little as 2 ml of water per gram of residue. Additional water did not significantly improve recovery.

The remainder of the potassium probably reacts with mineral matter in the bagasse to form water-insoluble compounds. Hood produces very little ash of its own, so higher recoveries are possible. Exxon digests the char from their



FIGURE 4. Effect of Water/Residue Ratio on Potassium Recovery 
CCG process with $\mathrm{Ca}(\mathrm{OH})_{2}$ to free additional water-soluble catalyst and increase recovery to 90\% (Furlong and Nahas 1978; Fant and Euker 1980). This method could probably be used with bagasse char to increase the recovery of potassium. Lower wash water/residue ratios should also be investigated.

The filtrate from the potassium recovery tests with wood was recycled and used in subsequent gasification tests, with no noticeable loss of catalyst effectiveness. 
.

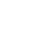
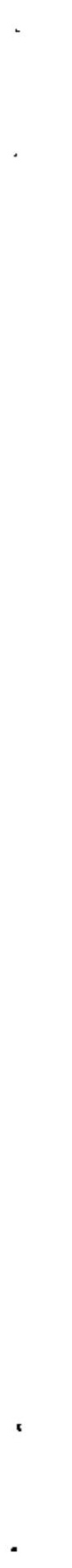
SECONDARY CATALYSTS

Pyrolysis of biomass yields a variety of volatile products $\left(\mathrm{CO}, \mathrm{CO}_{2}, \mathrm{H}_{2}\right.$, $\mathrm{CH}_{4}$, light hydrocarbon gases, tars, oils, soluble organics, etc). For many uses, however, a specific product is required (such as $\mathrm{CH}_{4}$ for high-Btu gas, or $\mathrm{H}_{2}$ and $\mathrm{CO}$ for methanol or hydrocarbon synthesis). By catalyzing the secondary reactions of pyrolysis products it is possible to tailor the product gas to specific applications. Bionass has several advantages over coal. Because of the high reactivity of biomass (only about 20 wt fixed carbon), high carbon conversion can be obtained at relatively low temperatures without the use of oxygen. The sulfur and ash contents of biomass are also quite low. These factors make it possible to use supported-metal catalysts in or directly following the gasifjer.

PRODUCTION OF SPECIFIC GASES

Studies at the University of Wyoming were among the first to use supported-metal catalysts in gasification. At $650^{\circ} \mathrm{C}$ and 2 to $3 \mathrm{~atm}$, a gas containing primarily methane and carbon dioxide $\left(31.7 \mathrm{MJ} / \mathrm{m}^{3}\right.$ on a $\mathrm{CD}_{2}$-free basis) was successfully produced in one step with a combination of potassium carbonate and commercial nickel methanation catalysts (Hoffman et al. 1972; Willson 1974). The nickel catalysts were eventually deactivated by the sulfur in the coal. Several approaches for alleviating the problem were studied but none was completely successful (Cox and Sealock 1974).

Catalytic biomass gasification studies were initiated at PNL in 1977. Catalysts and operating conditions were screened in a laboratory gasifier to optimize production of methane-rich gas, methanol or hydrocarbon synthesis gas $\left(2 \mathrm{H}_{2} / \mathrm{CO}\right)$, hydrogen-rich gas, and ammonia synthesis gas. Efforts to produce a co-rich gas were unsuccessful.

The reactions affected by the secondary catalysts are shown in Table 11 . The conditions and catalysts used for similar commercial applications in the hydrocarbon processing industry are also shown. For a11 the cases studied, elimination of tars, soluble organics, and light hydrocarbon gases was desirable. Catalysis of the shift reaction was usually necessary also. The primary 
TABLE 11. Secondary Reactions in Steam Gasification(a)

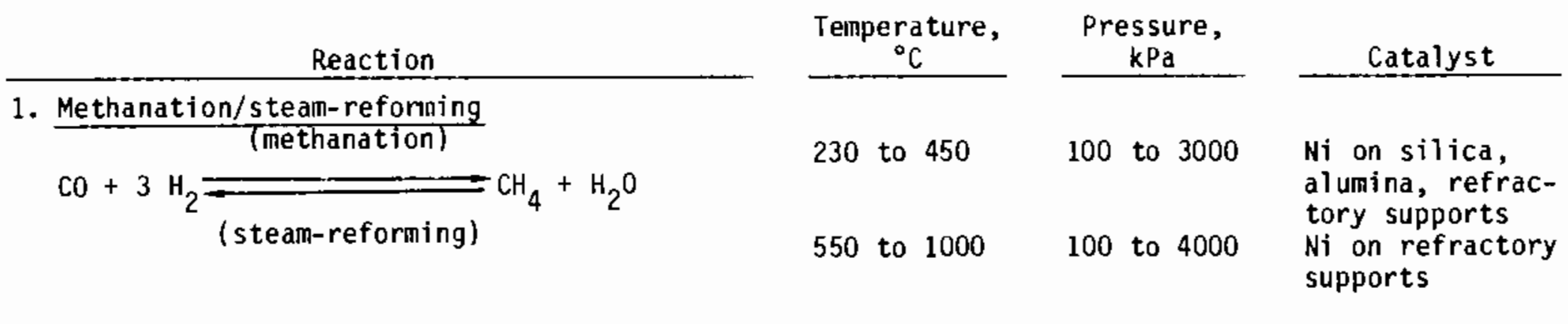

\section{Shift reaction}

$$
\mathrm{CO}+\mathrm{H}_{2} \mathrm{O} \longrightarrow \mathrm{H}_{2}+\mathrm{CO}_{2}
$$

100 to 2000

Metal oxides

$\mathrm{Fe}, \mathrm{Cr}, \mathrm{Cu}, \mathrm{Zn}$

3. Steam-reforming

Tars and other oxygenated hydrocarbons

$$
\mathrm{Tar}+\mathrm{H}_{2} \mathrm{O} \longrightarrow \mathrm{CO}+\mathrm{H}_{2}
$$

Light hydrocarbon gases

$$
\mathrm{C}_{n} \mathrm{H}_{\mathrm{m}}+\mathrm{H}_{2} \mathrm{O} \longrightarrow \mathrm{CO}+\mathrm{H}_{2}
$$

4. Hydrocracking

Tar $+\mathrm{H}_{2} \longrightarrow$ ighter hydrocarbons + gases

200 to 2000

450 to 600

100 to 4000

Ni on refractory supports

Ni on refractory supports

Ni-W on silicaalumina, Pd on zeolite

5. Catalytic cracking

Tar $\longrightarrow$ coke + lighter hydrocarbons + gases

(a) Thomas 1979; Venuto and Habib 1979; Rostrup-Nielson 1975; Gates, Katzer, and Schuit 1979; Satterfield 1980. 
difference among the cases was the fate of methane. For production of a methane-rich gas, catalysis of the methanation reaction was required; for the other cases, steam-reforming of methane to produce synthesis gas was necessary.

Silica-alumina cracking catalysts eliminated tars at $750^{\circ} \mathrm{C}$ and above, but had little effect on other gas-phase reactions (shift, reforming, or methanation). For production of synthesis gas, nickel-based catalysts were the most effective supported-metal catalysts tested. Others that were less effective included a CoMo $/ \mathrm{Al}_{2} \mathrm{O}_{3}$ hydrotreating catalyst, a $\mathrm{NiMo} / \mathrm{Al}_{2} \mathrm{O}_{3}$ hydrodesulfurization/ hydrocracking catalyst, a Pd hydrocracking catalyst, a CuZn shift catalyst, and a triple-promoted $\mathrm{Fe}_{2} \mathrm{O}_{3}$ ammonia synthesis gas catalyst. In general, these catalysts reduced or eliminated tars but had little effect on the other gas phase reactions, except that the Cuzn catalyst was an effective shift catalyst. Typical gas compositions achieved with some of these catalysts are shown in Table 12. A complete list of catalysts tested is given by Mudge et al. (1983).

Nickel catalysts were also found to be the most effective for the methanation reaction. Other types of catalysts tested included $\mathrm{SiO}_{2}-\mathrm{Al}_{2} \mathrm{O}_{3}$ cracking

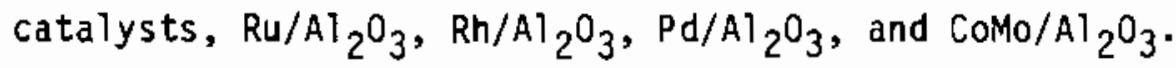

TABLE 12. Gas Compositions for Various Catalysts Tested for Synthesis Gas Production (a)

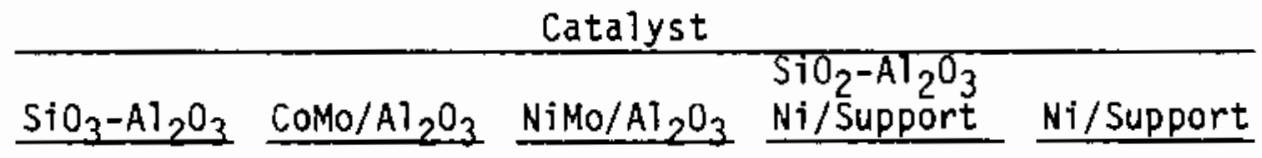

Gas Composition

$\begin{array}{lrrrrr}\mathrm{H}_{2} & 36 & 44 & 31 & 58 & 56 \\ \mathrm{CO} & 26 & 16 & 28 & 27 & 29 \\ \mathrm{CO}_{2} & 21 & 28 & 22 & 14 & 14 \\ \mathrm{CH}_{4} & 14 & 11 & 14 & 1 & 1 \\ \mathrm{C}_{2} \text { and } \mathrm{C}_{3} & 3 & 2 & 5 & - & -\end{array}$

(a) $750^{\circ} \mathrm{C}, 1 \mathrm{~atm}, \mathrm{H}_{2} \mathrm{O} /$ wood $\sim 0.7$. 
With fresh nickel catalysts the methanation/reforming reaction

$$
\mathrm{CH}_{4}+\mathrm{H}_{2} \mathrm{O} \rightleftharpoons \mathrm{CO}+3 \mathrm{H}_{2}
$$

is brought to equilibrium. Methane was almost completely converted to $\mathrm{H}_{2}$ and $\mathrm{CO}$ at $850^{\circ} \mathrm{C}$ and increased to about $25 \mathrm{~mol} \%$ at $550^{\circ} \mathrm{C}$. The minimum temperature for a single-bed process was set at $550^{\circ} \mathrm{C}$; below this temperature the rate of gas production was too low to be practical. Higher methane concentrations were achieved at lower temperatures using a dual-bed scheme in which the catalyst temperature was kept lower than the gasification temperature.

For the production of hydrocarbon synthesis gas, hydrogen, and ammonia synthesis gas, the secondary reactions are quite endothermic. Later PDU studies and a feasibility study of full-scale plants indicated that the maximum practical operating temperature would be 1 imited to about $750^{\circ} \mathrm{C}$ by heat input requirements and materials considerations.

These secondary reactions are quite fast in the presence of a catalyst. As Figure 5 shows, methane and phenol are almost completely converted to hydrogen and $\mathrm{CO}$ at residence times longer than $0.2 \mathrm{~s}$ at $750^{\circ} \mathrm{C}$.

Steam rates were varied from $0.1 \mathrm{~g} / \mathrm{g}$ wood up to $6 \mathrm{~g} / \mathrm{g}$ wood. Methane production is themodynamically favored at low steam rates while production of hydrogen is favored at high steam rates. At low steam rates $(<0.3 \mathrm{~g} / \mathrm{g}$ wood) carbon conversion begins to decrease, otherwise steam rate had little effect on conversion.

Table 13 shows the optimal operating conditions and catalyst type for the various product gases along with typical results for each case. Comparison of the obtained yields to the maximum theoretical yields (see Table 1) is enlightening. The best methane yield achieved was a little over $50 \%$ of the maximum theoretical. At high temperatures the yield is limited primarily by themodynamic equilibrium; at lower temperatures, by the kinetics of gasification. A dual-bed system operating at different temperatures is necessary to increase the yield. 


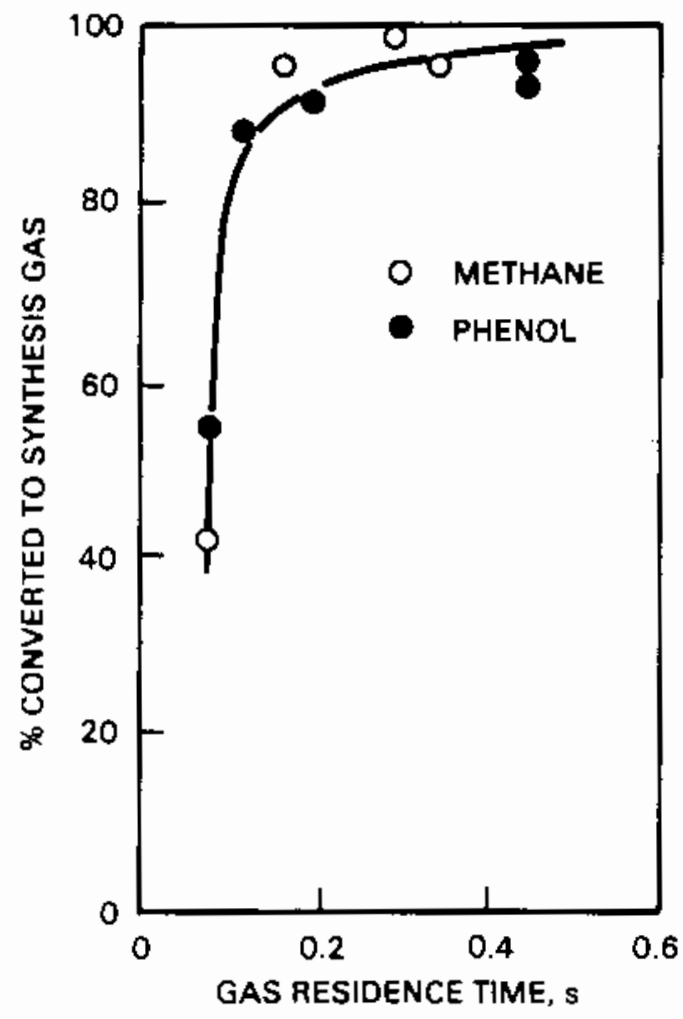

FIGURE 5. Steam-Reforming of Phenol and Methane

The yield of methanol synthesis gas is nearly $80 \%$ of theoretical and is limited by the kinetics of gasification and the ability of the catalyst to reform methane to synthesis gas. Hydrogen production, shown in Table 13, is about $70 \%$ of maximum theoretical and is 1 imited by gasification kinetics and, at high temperatures, by the water-gas shift equilibrium. Ammonia synthesis gas yield in Table 13 is about $60 \%$ of theoretical and is limited by the same factors as hydrogen production.

The type of nickel catalyst that was most effective varied from case to case. For methanation, catalysts with high nickel loadings (>30 wt $\% \mathrm{Ni}$ ) and high surface areas were most effective. They produced a gas containing essentially the equilibrium methane concentration. With lower-surface-area catalysts containing less nickel the methane concentration was somewhat lower. For synthesis gas production the difference in activity between various nickel catalysts was small. 
TABLE 13. Production of Specific Gases from Biomass by Steam Gasification

\begin{tabular}{|c|c|c|c|c|c|}
\hline & \multicolumn{5}{|c|}{ Product Gas/Catalyst } \\
\hline & \multicolumn{2}{|c|}{$\begin{array}{c}\text { Me thane-Rich } \\
\text { Gas }\end{array}$} & \multirow[t]{2}{*}{$\begin{array}{c}\text { Methanol } \\
\text { Synthesis } \\
\text { Gas } \\
\text { NickeT }\end{array}$} & \multirow{2}{*}{$\begin{array}{c}\text { Ammonia } \\
\text { Synthes is Gas } \\
\text { Nickel }+ \text { Shift }\end{array}$} & \multirow{2}{*}{$\begin{array}{l}\text { Hydrogen } \\
\text { Nickel+Shift }\end{array}$} \\
\hline & Nickel & NickeI & & & \\
\hline $\begin{array}{l}\text { Gasification } \\
\text { temperature, }{ }^{\circ} \mathrm{C}\end{array}$ & 650 & 550 & 750 & 650 & 750 \\
\hline $\begin{array}{l}\text { Catalyst } \\
\text { temperature, }{ }^{\circ} \mathrm{C}\end{array}$ & 350 & 550 & 750 & 650 & 750 \\
\hline Steam/wood, $g / g$ & 0.16 & 0.33 & 0.70 & 1.60 & 5.7 \\
\hline Air/wood, $g / g$ & -- & - & -- & 0.65 & - \\
\hline $\begin{array}{l}\text { Carbon conversion } \\
\text { to gas, s(a) }\end{array}$ & 50 & 68 & 90 & 65 & 78 \\
\hline \multicolumn{6}{|l|}{$\begin{array}{l}\text { Gas composition, } \\
\text { vol\% }\end{array}$} \\
\hline $\mathrm{H}_{2}$ & 5 & 30 & 53 & 51 & 64 \\
\hline $\mathrm{CO}_{2}$ & 42 & 34 & 16 & 21 & 30 \\
\hline CO & $\operatorname{tr}(b)$ & 11 & 28 & 7 & 6 \\
\hline $\mathrm{CH}_{4}$ & 53 & 25 & 3 & 3 & $\operatorname{tr}$ \\
\hline$c_{2}$ and $c_{3}$ & $\operatorname{tr}$ & $\operatorname{tr}$ & $\operatorname{tr}$ & $\operatorname{tr}$ & $\operatorname{tr}$ \\
\hline$N_{2}$ & - & -- & $\rightarrow$ & 18 & -- \\
\hline Yield/kg, $\mathrm{nm}^{3}$ & 0.25 & 0.22 & 1.4 & 1.3 & 1.25 \\
\hline
\end{tabular}

(a) No liquid products were formed when the catalysts were active. Char is the only other product.

(b) $\operatorname{tr}=$ trace quantity, probably less than $0.1 \%$.

Research on catalytic gasification of biomass with supported-metal catalysts is also under way in France (Anonymous 1983), Japan (Yamazaki et al. 1983; Yokayama et al. 1983), and Sweden (Lindman et a1. 1981; Ekstrom, Lindman, and Pettersson 1982). Typical results from these studies are shown in Table 14. All three use some form of nickel catalyst. The Japanese and Swedish studies are directed toward production of methanol or hydrocarbon synthesis gas and the gasification temperature, 700 to $750^{\circ} \mathrm{C}$, is the same as that used at PNL. 
TABLE 14. Typical Results of Various Catalytic Biomass

Conversion Studies with Nickel Catalysts

\begin{tabular}{|c|c|c|c|c|}
\hline & France & Japan & Sweden & U.S. \\
\hline Organization & $\begin{array}{l}\text { Azote et } \\
\text { Produits }\end{array}$ & $\begin{array}{l}\text { Toyohashi } \\
\text { University }\end{array}$ & $\begin{array}{l}\text { Royal Institute } \\
\text { of Technology }\end{array}$ & PNL \\
\hline $\begin{array}{l}\text { Reactor size } \\
\text { and type }\end{array}$ & $\begin{array}{l}\text { Pilot-scale, } \\
\text { dual vessel }\end{array}$ & $\begin{array}{l}\text { Laboratory, } \\
\text { batch, single } \\
\text { vessel }\end{array}$ & $\begin{array}{l}\text { Bench-scale and } \\
\text { pilot-scale, } \\
\text { dual vessel }\end{array}$ & $\begin{array}{l}\text { Laborator } \\
\text { and fluid } \\
\text { ized bed } \\
\text { PDU }\end{array}$ \\
\hline \multicolumn{5}{|l|}{$\begin{array}{l}\text { Operating } \\
\text { conditions }\end{array}$} \\
\hline $\begin{array}{l}\text { Catalyst } \\
\text { Reactant } \\
\text { Temperature, }{ }^{\circ} \mathrm{C} \\
\text { Pressure, } \mathrm{MPa}\end{array}$ & $\begin{array}{l}\text { Ni, proprietary } \\
\text { Steam } \\
\text { NA } \\
\text { NA }\end{array}$ & $\begin{array}{l}\mathrm{Ni} / \mathrm{Al}_{2} \mathrm{O}_{3} \\
\text { Steam } \\
700 \\
0.1\end{array}$ & $\begin{array}{l}\text { Ni-reforming } \\
\text { Steam, oxygen } \\
750,950 \\
3\end{array}$ & $\begin{array}{l}\mathrm{Ni} / \mathrm{Al}_{2} \mathrm{O}_{3} \\
\text { Steam } \\
700 \\
0.1\end{array}$ \\
\hline $\begin{array}{l}\text { Carbon conversion } \\
\text { to gas }\end{array}$ & NA & 87 & 98 & 80 \\
\hline \multicolumn{5}{|l|}{$\begin{array}{l}\text { Dry gas } \\
\text { composition, mo1\% }\end{array}$} \\
\hline $\begin{array}{l}\mathrm{H}_{2} \\
\mathrm{CO}\end{array}$ & $\begin{array}{l}50 \\
28\end{array}$ & $\begin{array}{l}56 \\
31\end{array}$ & $\begin{array}{l}43 \\
35\end{array}$ & $\begin{array}{l}55 \\
21\end{array}$ \\
\hline $\mathrm{CO}_{2}$ & $\begin{array}{l}16 \\
6\end{array}$ & $\begin{array}{l}11 \\
3\end{array}$ & $\operatorname{tr}^{22}(a)$ & $\begin{array}{l}21 \\
2\end{array}$ \\
\hline$C_{2}$ and $c_{3}$ & - & -- & - & - \\
\hline Tar & NA & NA & None & $t r$ \\
\hline
\end{tabular}

(a) $\operatorname{tr}=$ trace quantity, probably less than $0.1 \%$.

In Sweden, Lindinan et al. use oxygen as well as steam and a separate secondary catalyst bed operating at $950^{\circ} \mathrm{C}$. This setup results in very high carbon conversion to gas and almost complete elimination of hydrocarbon products.

Yamazaki et al. tested eight different metal oxide catalysts at $700^{\circ} \mathrm{C}$ in the presence of steam. The results are shown in Table 15. They concluded that $\mathrm{NiO} / \mathrm{Al}_{2} \mathrm{O}_{3}$ was the most effective catalyst for production of methanol synthesis gas, followed by $\mathrm{CuD}$ and $\mathrm{Fe}_{2} \mathrm{O}_{3}$. Several of the catalysts normally used for 
TABLE 15. Catalytic Gasificafipn with Various Metal Oxide
Catalysts at $700^{\circ} \mathrm{C}\left(\mathrm{a}^{2}\right.$

Catalyst

\begin{tabular}{|c|c|c|c|c|c|c|c|c|}
\hline & $\underline{\mathrm{V}_{2} \mathrm{O}_{5}}$ & $\mathrm{CoO}$ & $\mathrm{MoO}_{3}$ & $\mathrm{Mn}_{2} \mathrm{O}_{3}$ & $\mathrm{Cr}_{2} \mathrm{O}_{3}$ & $\mathrm{Cu} 0$ & $\mathrm{Fe}_{2} \mathrm{O}_{3}$ & NiO \\
\hline $\begin{array}{l}\text { Carbon conversion } \\
\text { to gas, } w t_{\%}^{\alpha}\end{array}$ & 81 & 83 & 81 & 77 & 77 & 89 & 79 & 87 \\
\hline \multicolumn{9}{|c|}{$\begin{array}{l}\text { Gas composition, } \\
\% \text { of total gas produced }\end{array}$} \\
\hline $\mathrm{H}_{2}$ & 46 & 44 & 40 & 58 & 44 & 59 & 55 & 56 \\
\hline $\mathrm{CO}$ & 6 & 13 & 7 & 18 & 30 & 19 & 32 & 31 \\
\hline $\mathrm{CH}_{4}$ & 2 & 1 & 1 & 11 & 12 & 7 & 7 & 3 \\
\hline $\mathrm{CO}_{2}$ & 46 & 42 & 52 & 13 & 15 & 15 & 5 & 11 \\
\hline $\begin{array}{l}\text { Synthesis gas yield, } \\
\mathrm{nm}^{3} / \mathrm{kg} \text { dry wood }\end{array}$ & 0.71 & 0.77 & 0.58 & 1.27 & 0.93 & 1.53 & 1.40 & 1.55 \\
\hline $\begin{array}{l}\text { Total gas yield, } \\
\mathrm{nm}^{3} / \mathrm{kg} \text { dry wood }\end{array}$ & 1.36 & 1.35 & 1.22 & 1.66 & 1.25 & 1.96 & 1.60 & 1.78 \\
\hline
\end{tabular}

(a) Data from Yamazaki et al. (1983).

oxidation reactions produced 1 arge quantities of $\mathrm{CO}_{2}$. Material balances indicate that much of the oxygen must come from the catalyst and not from the wood or steam.

CATALYST LIFETIME AND DEACTIVATION

An effective catalyst for catalytic steam gasification of biomass will:

- have the chemical and physical properties needed to promote the desired reactions

- be resistant to deactivation or be easily regenerated

- be physically durable in fluidized-bed operations.

Preliminary catalyst screening studies at PNL identified numerous active nickel-based catalysts and the optimal operating conditions for producing a variety of gases. Studies were then initiated to determine the active lifetime of nickel catalysts used for synthesis gas and methane-rich gas production in 
laboratory gasifiers. In addition, the attrition rate of various catalysts was measured in a laboratory fluidized bed.

Catalyst Deactivation Studies

Three possible causes of loss of catalyst activity were identified in laboratory tests: 1) catalyst fouling by carbon deposition, 2) loss of nickel surface area due to sintering, and 3) sulfur poisoning. The rate of catalyst deactivation was measured in terms of the weight of wood processed per unit weight of catalyst before deactivation. Some 1055 of activity is noted for all catalysts, so the presence of tars in the product gas was used to define the point at which a catalyst was deactivated.

In tests at $550^{\circ} \mathrm{C}$ all catalysts tested were deactivated quite rapidly. The active lifetime of the catalyst seers to be primarily related to the amount of metal surface area on the catalyst, as shown in figure 6 . The longest active lifetime achieved was $73 \mathrm{~g}$ wood/g catalyst.

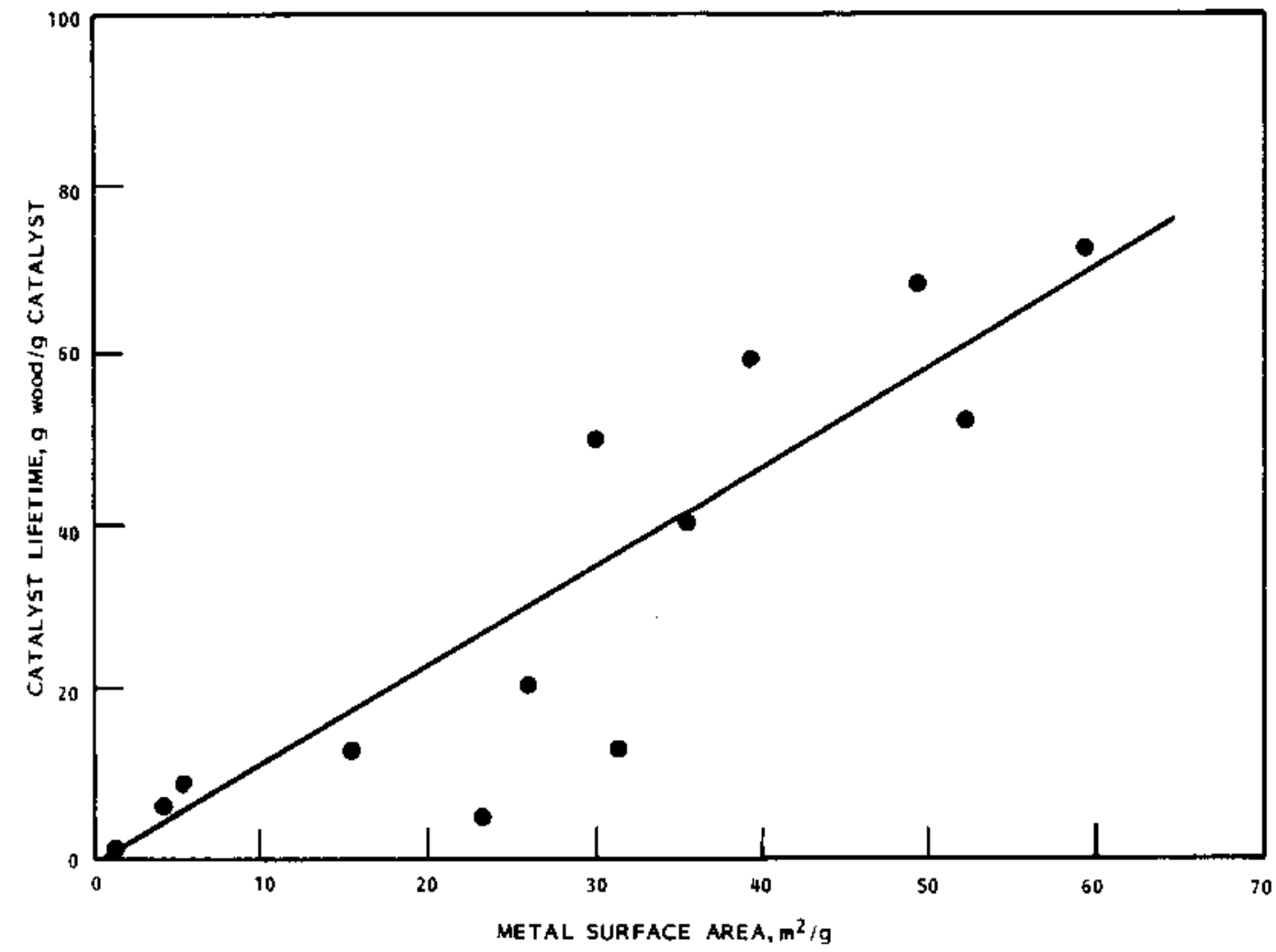

FIGURE 6. Effect of Metal Surface Area on Catalyst Lifetime at $550^{\circ} \mathrm{C}$ 
At $750^{\circ} \mathrm{C}$ some catalysts were completely deactivated rapidly, but several were found that retained much of their activity, as shown in Figure 7 . All of the catalysts lost some of their initial activity for reforming methane, which accounts for the small drop in activity for the NiCuMo/SiO${ }_{2}-\mathrm{Al}_{2} \mathrm{O}_{3}$ and $\mathrm{Ni} / \mathrm{a}-\mathrm{Al}_{2} \mathrm{O}_{3}$ (G-90C). Catalyst lifetimes ranged from 16 to $1470 \mathrm{~g}$ wood/g catalyst. Several of the tests, including the two shown in Figure 7 , were terminated while the catalyst was still active.

Carbon Deposition. Almost all catalysts tested at PNL had some carbon on them at the end of a run. Carbon deposition in the laboratory tests is primarily a function of temperature and catalyst type.

At $550^{\circ} \mathrm{C}$ carbon deposition was quite severe on all catalysts tested. Generally the catalysts contained 15 to $30 \mathrm{wt} \%$ carbon. At $750^{\circ} \mathrm{C}$, carbon deposition was significantly reduced, but was still a serious problem. The amount of carbon on the used catalysts at $750^{\circ} \mathrm{C}$ was generally less than $10 \mathrm{wt} \%$.

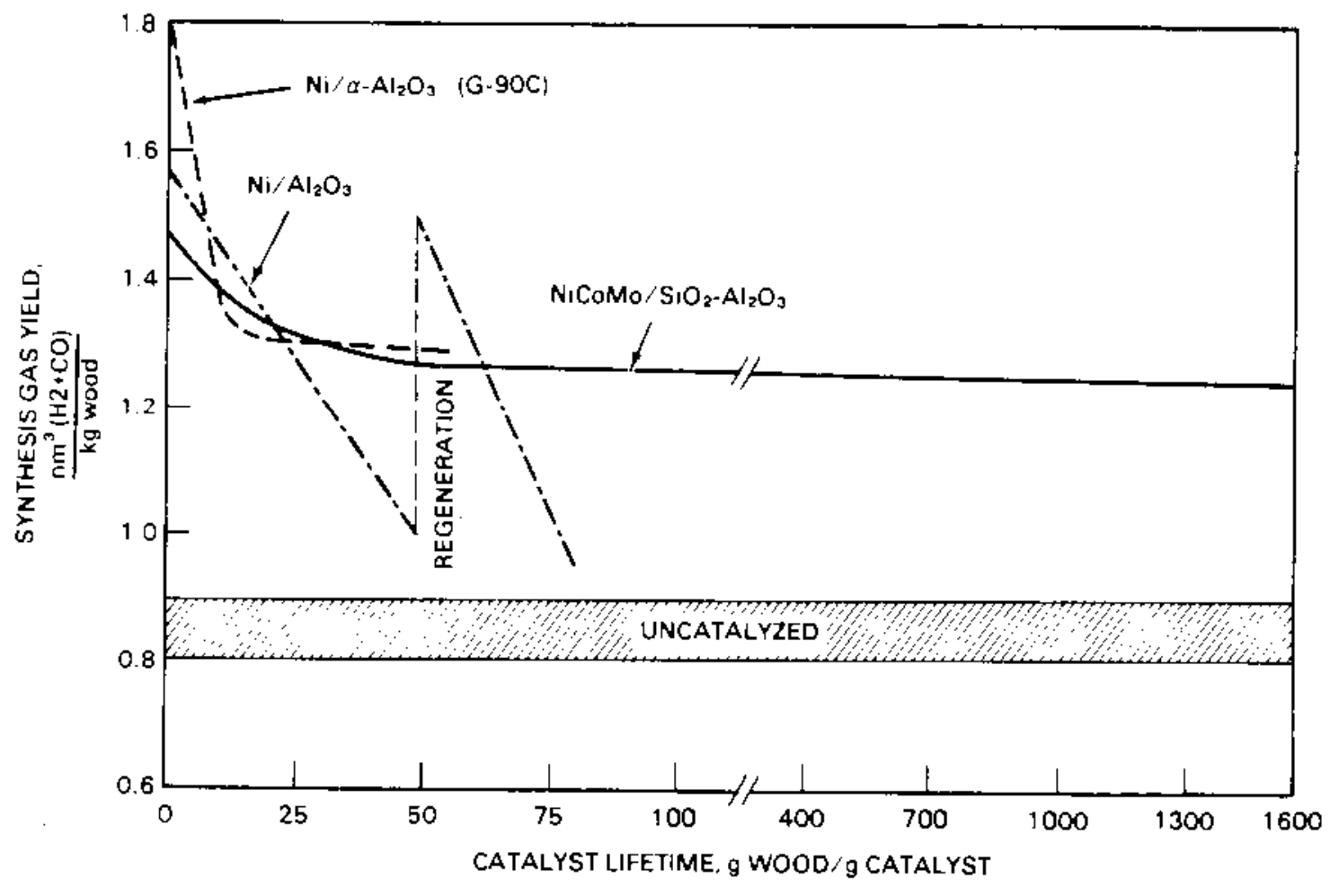

FIGURE 7. Effect of Catalyst Age on Yield at $750^{\circ} \mathrm{C}$ 
Studies in Sweden found that between $700^{\circ} \mathrm{C}$ and $850^{\circ} \mathrm{C}$ the nickel-based catalysts used in the MINO process were deactivated for methane-reforming, but not for tar-reforming or the water-gas shift reaction. Carbon deposition was shown to be the cause of deactivation. Above $900^{\circ} \mathrm{C}$, catalysts used for the MINO process were not deactivated, but at low steam rates carbon formation in the catalyst bed resulted in increased pressure drop (Ekstrom, Lindman, and Pettersson 1982). In limited PNL tests at $850^{\circ} \mathrm{C}$ it appeared that carbon deposition was less than at $750^{\circ} \mathrm{C}$.

The effect of catalyst type on carbon deposition was most apparent at $750^{\circ} \mathrm{C}$, as shown in Table 16 . Many commercial nickel catalysts such as $\mathrm{Ni}-3266$ and $\mathrm{C}-13-3$ were deactivated for tar-reforming at lifetimes of less than $100 \mathrm{~g}$ wood/g catalyst. However, three types of catalysts show promise for achieving economic lifetimes:

- trimetallic catalysts containing NiCuMo or NiCoMo

- steam-reforming catalysts supported on low-surface-area ceramic materials such as a-alumina, magnesia, and magnesium aluminum spinel

- catalysts doped with alkali.

TABLE 16. Carbon Deposition on Catalysts Used for Methanol Synthesis Gas at $750^{\circ} \mathrm{C}, 1 \mathrm{~atm}$

\begin{tabular}{|c|c|}
\hline & Catalyst \\
\hline \multicolumn{2}{|c|}{$\begin{array}{l}\text { Harshaw } \mathrm{Ni}-3266 \\
\text { United } \mathrm{C}-13-3\end{array}$} \\
\hline Grace & $\begin{array}{l}\mathrm{NiCOMo} / \mathrm{SiO}_{2}-\mathrm{Al} 1_{3}, 2 \% \text { Na } \\
\mathrm{NiCuMo} / \mathrm{Al}_{2} \mathrm{O}_{3}, 2 \% \mathrm{Na} \\
\mathrm{NiCOMo} / \mathrm{Al}_{2} \mathrm{O}_{3} \\
\mathrm{NiCOMo} / \mathrm{Al}_{2} \mathrm{O}_{3}, 2 \% \mathrm{Na} \\
\mathrm{NiCuMo} / \mathrm{SiO}_{2}-\mathrm{Al}_{2} \mathrm{O}_{3} \\
\mathrm{NiCCMO} / \mathrm{SiO}_{2}-\mathrm{Al}_{2} \mathrm{O}_{3}(\mathrm{a})\end{array}$ \\
\hline $\begin{array}{l}\text { United } \\
\text { PNL } K_{2} \\
\text { PNL Ni }\end{array}$ & $\begin{array}{l}\mathrm{G}-9 \mathrm{OC} \\
\mathrm{CO}_{3} / \mathrm{SiO}_{2}-\mathrm{Al}_{2} \mathrm{O}_{3} \\
\mathrm{i} / \mathrm{Na}_{2} \mathrm{CO}_{3} / \mathrm{Al}_{2} \mathrm{O}_{3}\end{array}$ \\
\hline
\end{tabular}

Carbon on Used Catalyst, wto

(a) Tested at $650^{\circ} \mathrm{C}$. 
A NiCoMo/ $\mathrm{SiO}_{2}-\mathrm{Al}_{2} \mathrm{O}_{3}$ catalyst doped with $2 \mathrm{wt} \%$ Na reached a lifetime of $1470 \mathrm{~g} \mathrm{wood} / \mathrm{g}$ catalyst. At the end of the run $6 \mathrm{wt} \%$ carbon had accumulated on the catalyst, which had lost some of its activity for methane-reforming but was still active for tar-reforming and the shift reaction.

A steam-reforming catalyst, nickel on a-alumina (G-90C), reached a lifetime of 60 , maintained much of its initial activity, and had essentially no carbon on it at the end of the run. This was the only tested nickel-based catalyst on which carbon did not accumulate. A catalyst made at PNL containing $25 \mathrm{wt} \% \mathrm{Na}_{2} \mathrm{CO}_{3}$ and $10 \mathrm{wt} \% \mathrm{Ni}$ had very little carbon on it after a lifetime of 90 but its initial activity was significantly less than that of other nickel catalysts.

In the laboratory gasifier tests with $\mathrm{NiCuMo} / \mathrm{SiO}_{2}-\mathrm{Al}_{2} \mathrm{O}_{3}$ and $\mathrm{NiCOMo} / \mathrm{SiO}_{2}-$ $\mathrm{Al}_{2} \mathrm{O}_{3}$, steam rates between $0.5 \mathrm{~g}$ and $6 \mathrm{~g} / \mathrm{g}$ wood had little effect on carbon deposition at $750^{\circ} \mathrm{C}$. In model compound studies, carbon deposition with phenol was low (0.5 to 3.4 wt\% on the catalyst) at steam rates above 3 moles steam/mole of carbon (Table 17). At lower steam rates carbon deposition increased dramatically. This represents a much lower steam/tar (phenol) ratio than that to which the catalyst is exposed in the laboratory gasifier.

Only 1 imited information has been obtained from the POU with respect to carbon deposition and catalyst lifetime but it appears that coking may be more

TABLE 17. Effect of Steam Rate on Carbon Deposition with Phenol

\begin{tabular}{|c|c|c|}
\hline Moles Steam/Mole Carbon & $\begin{array}{c}\text { Space Velocity } \\
\text { (GHSV) }\end{array}$ & $\begin{array}{l}\text { wt\% Carbon } \\
\text { on Catalyst }\end{array}$ \\
\hline $\begin{array}{l}5.8 \\
4.7 \\
4.4 \\
3.7 \\
3.6 \\
1.2 \\
1.2\end{array}$ & $\begin{array}{l}2000 \\
1900 \\
3500 \\
2400 \\
2400 \\
4300 \\
1100\end{array}$ & $\begin{array}{c}3.4 \\
(a) \\
(a) \\
0.4 \\
1.6 \\
22.4 \\
18.9\end{array}$ \\
\hline
\end{tabular}

(a) Part of a series of runs. Wt\% carbon at the end of the series was 6.3. 
severe in the PDU. Catalysts usually pick up 10 to $20 \mathrm{wt} \%$ carbon by the end of a one-day PDU run. It is not clear whether this increase in carbon deposition is due to 1) intrinsic differences between the fluidized-bed PDU and the fixedbed laboratory gasifiers or 2) the unsteady-state operations of the PDU. Figure 8 shows the loss of activity for a series of runs with $\mathrm{Ni} / \mathrm{Al}_{2} \mathrm{O}_{3}$ in 1980. The loss of activity seems to correspond to the shutdowns between runs. When the system operated smoothly, as in runs 3 and 5 , the catalyst appeared to maintain its activity. After run 4 the catalyst was regenerated with steam at $750^{\circ} \mathrm{C}$. Figure 9 shows the activity of $\mathrm{NiCuMo} / \mathrm{SiO}_{2}-\mathrm{Al}_{2} \mathrm{O}_{3}$ catalyst with bagasse and wood. With wood there was some noticeable loss of activity near the end of the run but it occurred immediately following a plant upset. With bagasse there was a gradual loss of activity that apparently was a function of the sulfur content of the bagasse (see section on sulfur poisoning).

Although loss of activity seems to correspond to unsteady-state operations, similar conditions were encountered many times in the laboratory lifetime runs without loss of activity.

Sulfur Poisoning. Hydrogen sulfide is a known poison for nickel catalysts (Rostrup-Nielson 1975; Satterfield 1981). Bionass contains relatively small

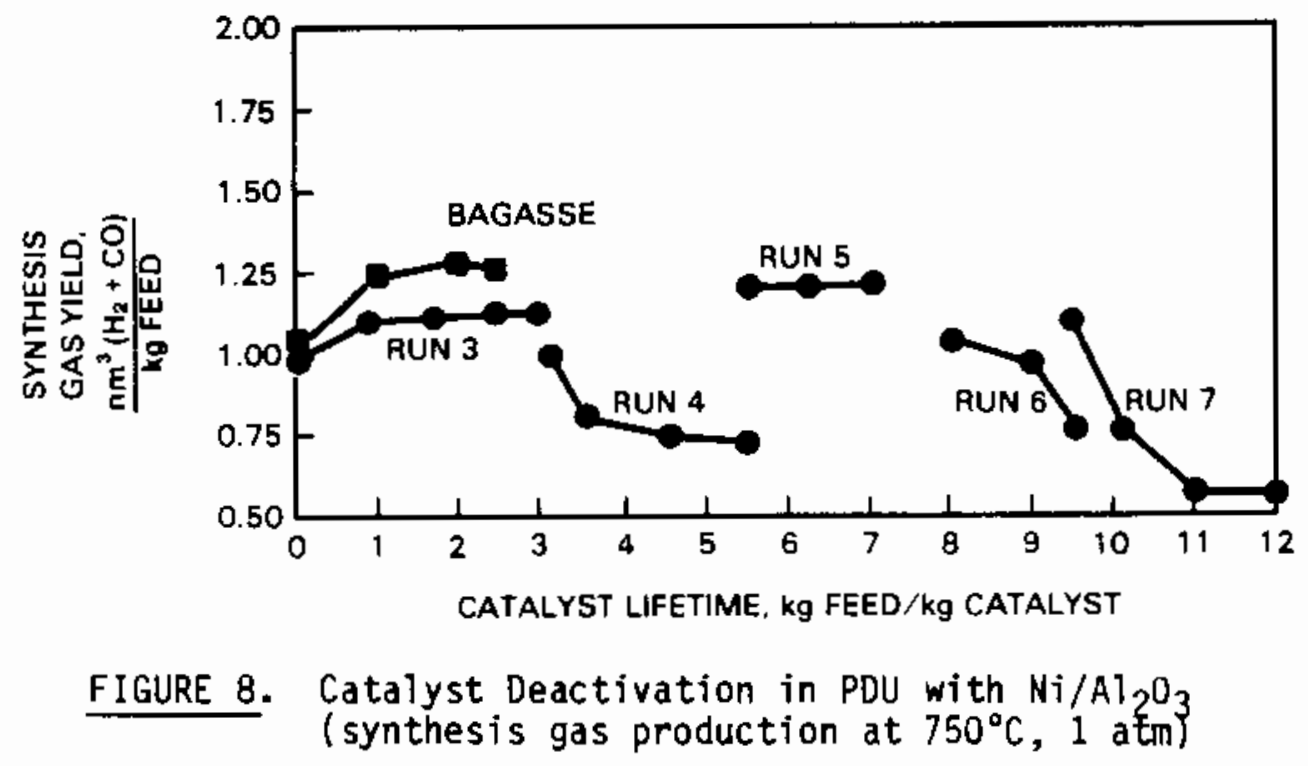




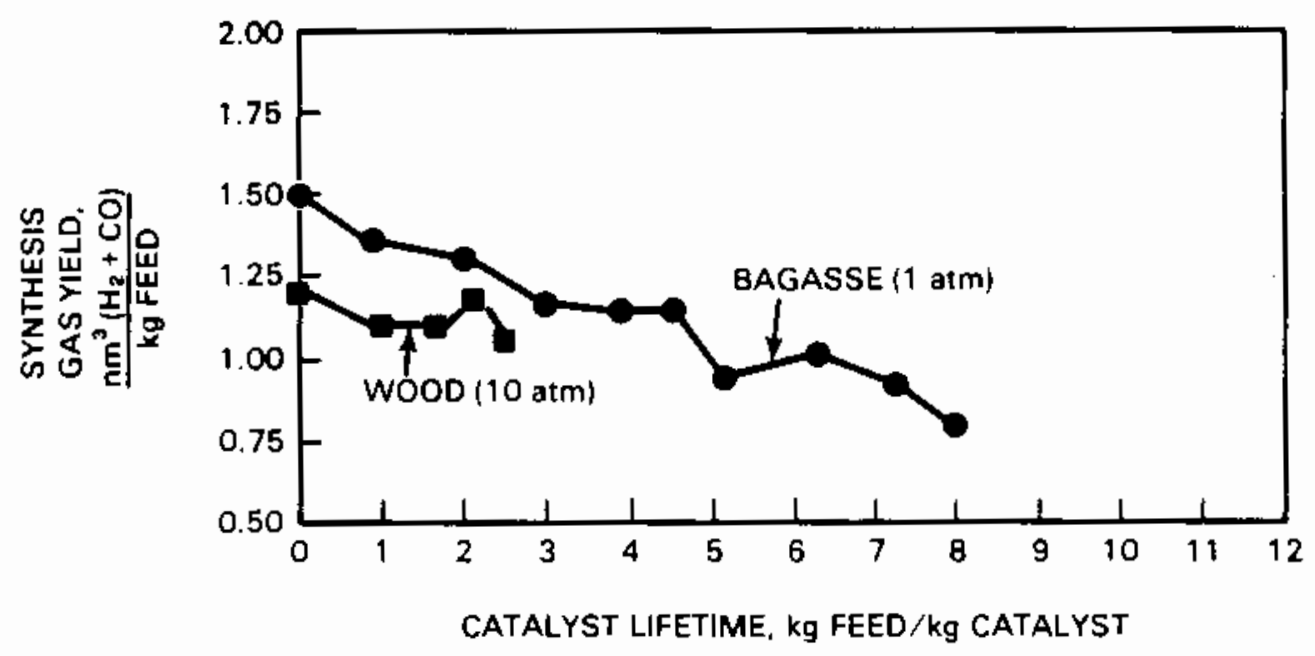

FIGURE 9. Catalyst Deactivation in PDU with $\mathrm{NiCuMo} / \mathrm{SiO}_{2}-\mathrm{Al}_{2} \mathrm{D}_{3}$ (synthesis gas production at $750^{\circ} \mathrm{C}$ )

quantities of sulfur compared to other solid fuels; however, sulfur poisoning still must be considered as a possible cause of catalyst deactivation. Table 18 lists the sulfur contents of various biomass materials and the $\mathrm{H}_{2} \mathrm{~S}$ contents of the raw gas produced by uncatalyzed steam gasification at $750^{\circ} \mathrm{C}$.

With wood as a feedstock, there were no indications that sulfur contributed to catalyst deactivation at any of the conditions tested. In recent tests with bagasse, however, sulfur poisoning appeared to be one of the major causes of catalyst deactivation. Two factors indicate that the deactivation mechanism with bagasse is different from that observed with wood:

- Catalyst lifetimes were much shorter ( $<100 \mathrm{~g}$ wood/g catalyst).

- A catalyst with greater active-metal surface area $\left(\mathrm{Ni}^{2} / \mathrm{Al}_{2} \mathrm{O}_{3}\right)$ takes longer to deactivate than does $\mathrm{NiCuMo} / \mathrm{SiO}_{2}-\mathrm{Al}_{2} \mathrm{O}_{3}$.

That $\mathrm{H}_{2} \mathrm{~S}$ is involved in the deactivation mechanism with bagasse is suggested by the following:

- There is a close correlation between the amount of sulfur on the catalysts when they lose activity and the amount of sulfur required to sulfide the active-metal surface area of the catalyst.

- There is good correlation between the time that should be required to sulfide the catalyst and the time at which deactivation occurs. 
TABLE 18. Sulfur Analyses for Biomass Gasification

\begin{tabular}{|c|c|c|}
\hline & $\begin{array}{c}\text { ppm S by weight } \\
\text { in feed }\end{array}$ & 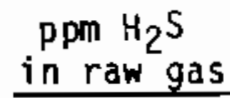 \\
\hline $\begin{array}{l}\text { Wood } \\
\text { Bark } \\
\text { Bagasse }\end{array}$ & $\begin{array}{r}47 \text { to } 145 \\
204 \text { to } 330 \\
230 \text { to } 375\end{array}$ & $\begin{array}{l}20 \text { to } 30 \\
-- \\
80 \text { to } 240\end{array}$ \\
\hline
\end{tabular}

- Mixing a ZnO sulfur guard catalyst with a nickel catalyst extends the life of the nickel catalyst.

Wood does contain some sulfur, although less than bagasse, and $\mathrm{NiCoMo/}$ $\mathrm{SiO}_{2}-\mathrm{Al}_{2} \mathrm{O}_{3}$ ran for over 1000 hours in a laboratory test with wood without deactivating. Rostrup-Nielson (1975), in studies of chemisorption of hydrogen sulfide on steam-reforming catalysts, found the chemisorption of hydrogen sulfide on nickel to be reversible, the coverage on the catalyst being a function of the ratio $\mathrm{pH}_{2} \mathrm{~S} / \mathrm{pH}_{2}$. The amount of absorbed sulfur in equilibrium with the $\mathrm{H}_{2} \mathrm{~S}$ in the gas increases with increasing $\mathrm{H}_{2} \mathrm{~S}$ concentration until constant fractional coverage of the surface is reached. It appears that the suifur level in wood allows enough of the nickel on the catalyst to remain exposed and active.

Heavy carbon deposition was also found on catalysts used with bagasse, particularly those from the PDU, and one could conclude that the sulfided catalysts are more susceptible to the carbon deposition that actually causes loss of activity. However, it is generally agreed that sulfiding nickel-reforming catalysts decreases carbon formation on the catalyst (Rostrup-Nielson 1975; McCarty et al. 1981).

From these studies it is not possible to positively identify the exact mechanism for deactivation with bagasse, but it definitely appears to be a function of the sulfur content. Coking may also play a part but the exact relationship between the sulfur adsorption and carbon deposition is not known.

Sintering. Thermal sintering, or agglomeration, can also cause loss of catalyst activity. Sintering is the loss of metal surface area due to growth in nickel particle size on the catalyst support. Nickel is mobile at high temperatures and the small crystals agglomerate to form larger particles, reducing the nickel surface area. 
Sintering is particularly troublesome with high-surface-area dispersed metal catalysts such as Harshaw Ni-3266. A sample of $\mathrm{Ni}-3266$, which had 20 wt\% carbon on it after a 1 ifetime test, was regenerated with steam at $750^{\circ} \mathrm{C}$ for 64 hours. Despite removal of all the carbon the catalyst was not active and the surface area as measured by hydrogen chemisorption was the same as that of the coked catalyst, and much less than that of the fresh catalyst. On the other hand, a sample of $\mathrm{NiCOMo} / \mathrm{SiO}_{2}-\mathrm{Al}_{2} \mathrm{O}_{3}$ catalyst, with a much lower surface area than a fresh catalyst, showed a significant increase in activity and surface area after steaming at $750^{\circ} \mathrm{C}$ to remove carbon.

The fact that regeneration of $\mathrm{Ni}-3266$ did not increase $i$ ts metal surface area indicates that sintering was responsible for much of the surface area loss. With $\mathrm{NiCOMO} / \mathrm{SiO}_{2}-\mathrm{Al}_{3} \mathrm{O}_{3}$, the metal surface area increased after regeneration although it did not return to its original value. Some of the surface area was permanently lost, due probably to sintering. Pederson, Skov, and RostrupNielson (1980) studied sintering of a high-surface-area methanation catalyst $\left(\mathrm{Ni} / \mathrm{YAl}_{2} \mathrm{O}_{3}\right)$ and a low-surface-area steam-reforming catalyst ( $\left.\mathrm{Ni} / \mathrm{ceramic}\right)$. The $\mathrm{Ni} / \mathrm{YAl}_{2} \mathrm{O}_{3}$ lost over $70 \%$ of its surface area at $750^{\circ} \mathrm{C}$ while the $\mathrm{Ni} /$ ceramic lost less than $10 \%$ of $i$ ts surface area.

Tarmann's rule says that sintering can be expected at temperatures 0.5 times the melting point in degrees $K$ (Gregg 1965). The melting point of nickel is $1726 \mathrm{~K}$, so sintering can be expected at temperatures above $590^{\circ} \mathrm{C}(863 \mathrm{~K})$. However, for supported catalysts the metal particles are restricted to a size less than the pore diameter of the support. This means that a stabilized micropore system in the support can help prevent sintering of the nickel crystals.

At the temperatures encountered in the gasifier, even some support materials lose their porosity and are not suitable supports. Most industrial catalysts for steam-reforming, which operates at temperatures similar to those in gasification, use catalyst carrier materials of a-alumina, Mgo, and magnesium aluminum spinel. High-surface-area supports such as $\gamma$ - or $n-\mathrm{Al}_{2} \mathrm{O}_{3}$ are susceptible to sintering at high temperatures and can not be used without stabilizing additives. Silica, being volatile at high temperatures in steam, is now normally excluded from catalysts for steam-reforming (Marschner and Renner 1982; Rostrup-Nielson 1975). 
In summary, sintering of nickel can be expected at gasification temperatures. Sintering can be controlled by choosing a support with sufficient surface area $\left(>5 \mathrm{~m}^{2} / \mathrm{g}\right)$ that retains its micropore structure at gasification temperatures.

Attrition

Another factor which must be considered when evaluating catalyst lifetime is physical breakdown, or attrition, of the catalyst. If the catalyst is located outside of the gasifier in a fixed bed, attrition will not be a serious problem. However, if the catalyst is the fluidizeable material in the gasifier bed, attrition may be significant.

Because the wood must also be fluidized the catalyst particles used in PNL's PDU gasifier are quite large (30 to 80 mesh) for fluidized-bed catalysts. Oata for this catalyst size are limited but it appears that fluidization is not as good and attrition is higher than with smaller particles (Kono 1980; Wen and Dutta 1978).

The attrition rate of three different catalysts $\left(\mathrm{Al}_{2} \mathrm{O}_{3}, \mathrm{Ni} / \mathrm{Al}_{2} \mathrm{O}_{3}\right.$, and NiCuMo $\left./ \mathrm{SiO}_{2}-\mathrm{Al}_{2} \mathrm{O}_{3}\right)$ in the 30 -to-80 mesh size range was measured in laboratoryscale fluidized beds. At flow rates just above the minimum fluidization velocity the steady-state rate of attrition ranged from 0.004 to 0.007 wt\% per hour using air at ambient temperature as the fluidizing gas. At $750^{\circ} \mathrm{C}$ with steam the rate of attrition was 0.007 to $0.008 \mathrm{wto}$ per hour. This rate is quite low; however, as the superficial linear velocity $\left(V_{0}\right)$ increases, the rate of attrition increases dramatically. For the $\mathrm{Ni} / \mathrm{Al}_{2} \mathrm{O}_{3}$ catalyst it was a function of $\mathrm{V}_{0}{ }^{2.1}$; for the $\mathrm{NiCuMo} / \mathrm{SiO}_{2}-\mathrm{Al}_{2} \mathrm{O}_{3}$ it varied as $\mathrm{V}_{0}{ }^{3}$.

The attrition rate in the fluidized-bed PDU has not been measured but appears to be higher than observed in the laboratory tests. The high superficial velocities used in the PDU, up to five times the minimum, are partially responsible for this. Another possibility is that carbon on the catalyst inay weaken the particle and increase attrition. In the laboratory fluidized bed the attrition rate with a coked catalyst was about double that of a fresh catalyst. The design of the PDU gasifier also allows catalysts to fall back into the feed screw where some of the catalysts may be crushed. 
.

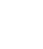




\section{MECHANISMS OF CATALYTIC GASIFICATION}

The focus of the PNL catalytic gasification studies has been to develop a process for producing specific gases in one step. In the course of these efforts it became apparent that a better understanding of the mechanisms involved could lead to significant process improvements in several areas. Mechanistic studies were therefore initiated to develop a fundamental understanding of 1) the overall effect of alkali carbonates on pyrolysis/gasification, and 2) the causes of coking on secondary catalysts.

High-temperature steam gasification of biomass is often considered to be a two-step process: rapid pyrolysis followed by steam gasification of the remaining residue. However, Shafizadeh and Fu (1973) have shown that tar-forming reactions predominate during high-temperature pyrolysis and that levoglucosan is the prinary component of the tar. At the Solar Energy Research Institute (SERI), MiIne, Evans and Solty (1983) have shown that the decomposition pathways are basically unaffected by temperature in the range from 500 to $900^{\circ} \mathrm{C}$, with levoglucosan being the primary product.

These primary tars undergo secondary thermal reactions such as dehydration, disproportionation, decarboxylation, and decarbonylation to produce gases ( $\mathrm{CO}$, $\mathrm{CO}_{2}, \mathrm{CH}_{4}$ ), water-soluble organics (acids, ketones, alcohols, etc.), char, and water (Shafizadeh 1982).

Char from rapid pyrolysis and secondary tar reactions continues to pyrolyze and reacts with steam (carbon/steam reaction) to produce additional gases. Gases from pyrolysis, secondary tar reactions, and gasification of char can undergo various secondary reactions such as water-gas shift, methanation, and reforming. Only the shift reaction is rapid enough to be significant in the absence of catalysts.

The mechanistic studies showed that catalysts affect the entire process, as shown in Figure 10 . The effect of catalysts and primary tars on one another appears to be especially important. 


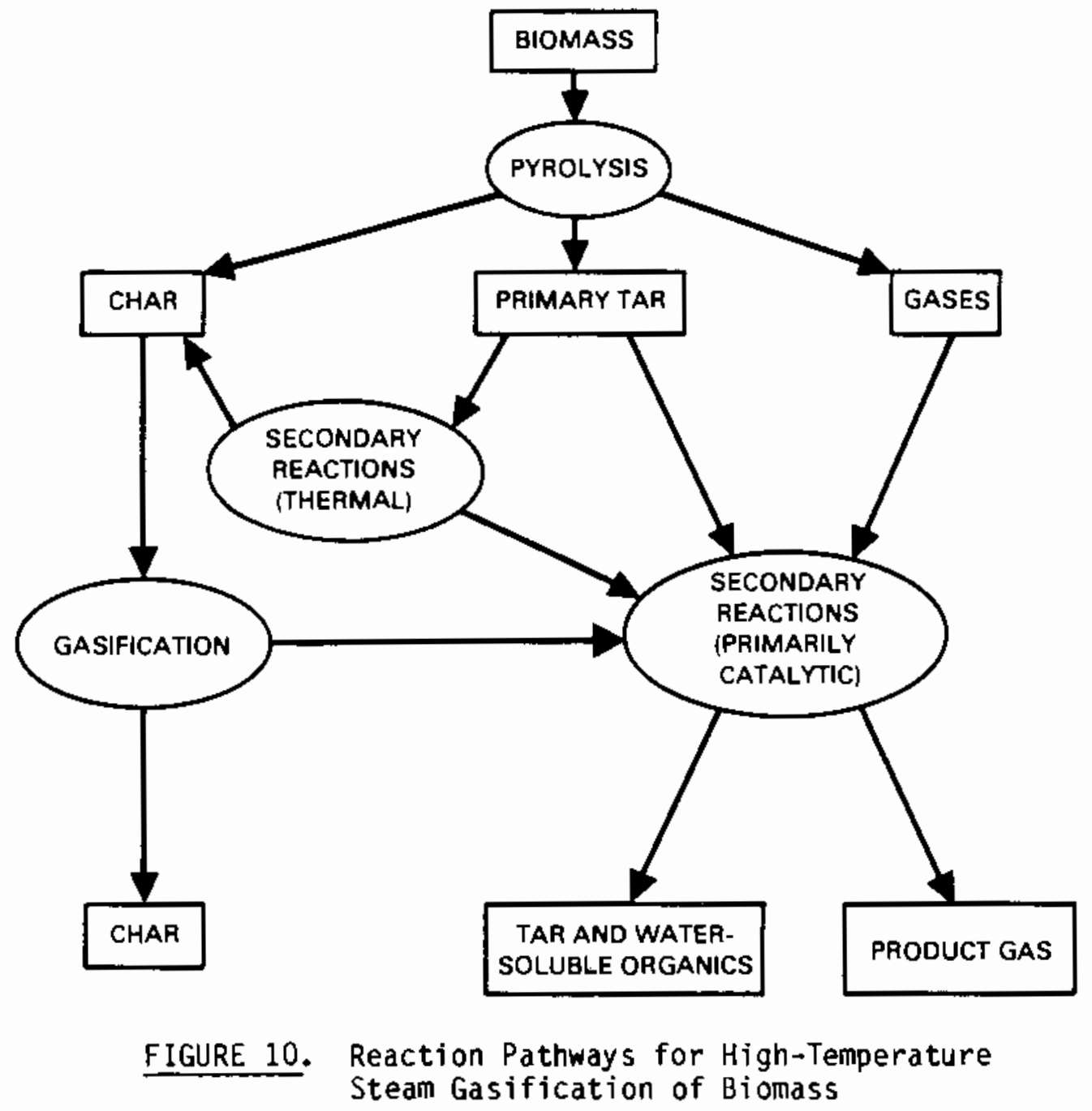

PRIMARY CATALYSTS

Laboratory gasification tests showed that alkali carbonates doped on biomass increase the yield of char from pyrolysis. The char was more reactive than uncatalyzed char and the rate of gasification was increased two- to ninefold. In the fluidzed-bed PDU, however, the net effect of adding $\mathrm{K}_{2} \mathrm{CO}_{3}$ was to increase the yield of char. Laboratory and PDU tests at $750^{\circ} \mathrm{C}$ both showed that aikali carbonates significantly reduced the tars and decreased the yield of methane. 
Pyrolysis

Analysis of high-temperature $\left(300\right.$ to $\left.500^{\circ} \mathrm{C}\right)$ pyrolysis tar from cellulose shows levoglucosan as a primary component along with other sugar units (Shafizadeh and Fu 1973; Milne, Evans, and Solty 1983). Fundamental pyrolysis studies at SERI have shown that addition of alkali catalysts such as $\mathrm{K}_{2} \mathrm{CO}_{3}$, $\mathrm{Na}_{2} \mathrm{CO}_{3}$, and $\mathrm{KOH}$ eliminates formation of levoglucosan during pyrolysis. These catalysts apparently inhibit transglycosylation, which has been shown to be the primary pathway for decomposition of cellulose to tar (Milne, Evans, and Solty 1983). This appears to be one mechanism by which alkali carbonates reduce the yield of tars.

Shafizadeh (1982) has also shown that alkali increases conversion of levoglucosan to char and gases. This could also partially account for the effect of alkali on gasification. Most of the preceeding discussion is based on cellulose but the mechanisms fit very well with the overall results obtained with wood in both laboratory and PDU studies at PNL.

In high-temperature gasification of biomass the amount of methane produced during pyrolysis generally exceeds the equilibrium methane concentration. The effect of alkali is to reduce this concentration toward the equilibrium concentration, although equilibrium is not achieved. Laboratory studies in a gas phase reactor have shown that neither $\mathrm{K}_{2} \mathrm{CO}_{3}$ nor biomass char, nor a combination of the two, catalyzes the decomposition of methane at temperatures below $800^{\circ} \mathrm{C}$. Furthermore, analysis of gases from the top of the continuous reactor during a run with $\mathrm{K}_{2} \mathrm{CO}_{3}$-impregnated wood showed a reduction in the methane produced (compared to uncatalyzed runs), and no further reduction was noted after the gas had passed through the char bed and out of the reactor. This suggests that alkali carbonates alter the pyrolysis reaction pathways so as to reduce the formation of methane, rather than acting as a heterogeneous catalyst for reforming methane to $\mathrm{H}_{2}$ and $\mathrm{CO}$. Veraa and Bell (1978) also found that high concentrations of $\mathrm{K}_{2} \mathrm{CO}_{3}$ suppressed formation of methane during coal gasification. 


\section{Gasification}

Alkali carbonates increase the rate of biomass char gasification, although the effect is not as dramatic as has been reported for some coals (see Table 4 ). The mechanism of alkali-catalyzed gasification of char has been the subject of much research. (a) Mckee (1983) has proposed a mechanism involving the carbothermic reduction of alkalj carbonates to alkali metal vapor, as shown below:

$$
\begin{aligned}
& \text { 1. } \mathrm{K}_{2} \mathrm{CO}_{3}+2 \mathrm{C} \longrightarrow 2 \mathrm{~K}+3 \mathrm{CO} \\
& \text { 2. } 2 \mathrm{~K}+2 \mathrm{H}_{2} \mathrm{O} \longrightarrow 2 \mathrm{KOH}+\mathrm{H}_{2} \\
& \text { 3. } 2 \mathrm{KOH}+\mathrm{CO} \longrightarrow \mathrm{K}_{2} \mathrm{CO}_{3}+\mathrm{H}_{2} \\
& \text { 4. } 2 \mathrm{C}+2 \mathrm{H}_{2} \mathrm{O} \longrightarrow 2 \mathrm{CO}+2 \mathrm{H}_{2}
\end{aligned}
$$

Mckee indicated that alkali intermediates may also interact with the substrate to form free radicals or intercalation compounds, but that insufficient data were available to assess the role of these species in the gasification process. The actual mechanism controlling alkali-catalyzed gasification is still the subject of much debate.

Secondary Reactions

As previously indicated, alkali catalysts reduce the yield of tars, oils, soluble organics, and light hydrocarbon gases from high-temperature gasification of biomass. This is somewhat surprising, as catalysis of decomposition reactions such as dehydrogenation, dehydration, and steam-reforming normally occurs with Group VIII metals, not with alkalis. That alkali carbonates apparently alter the pyrolysis reaction pathways accounts for much of this effect. However, in the course of recent PNL studies it was discovered that alkali carbonates do act as heterogeneous catalysts for some secondary reactions during biomass gasification.

The PNL study used supported- $\mathrm{Na}_{2} \mathrm{CO}_{3}$ as a secondary catalyst in the fixedbed continuous-feed laboratory reactor, and found that this catalyst reduced tars and soluble organics but had little effect on gas composition. Hallen,

(a) Mckee et al. 1983; McCoy 1983; Veraa and Bell 1978; Wood et a1. 1983; Wen 1980. 
Sealock, and Cuel10 (1982) found much the same result in dual-vessel batch gasification tests where $\mathrm{Na}_{2} \mathrm{CO}_{3}$ was kept in a basket physically separated from the wood.

Hallen, Sealock, and Cuello also investigated the effect of alkali carbonates on the decomposition of model compounds that have been reported as pyrolysis products from cellulose. Alkali carbonates catalyzed the decomposition of alcohols, organic acids, and aldehydes, but had little effect on ketones (Table 19). Especially surprising is the catalytic effect of alkali carbonates on alcohol dehydrogenation, as there is no reference to the use of alkali carbonates as alcohol dehydrogenation catalysts in the literature (Hallen, Sealock and Cuello 1982). PNL also studied the catalytic effect of $\mathrm{K}_{2} \mathrm{CO}_{3}$ on decomposition of methane and phenol in the gas phase reactor at $750^{\circ} \mathrm{C}$. Potassium carbonate catalyzed the decomposition of phenol but was not active for converting methane.

As discussed earlier, studies at PNL indicate that the alkali carbonates suppress formation of methane during pyrolysis and do not act as heterogeneous catalysts to reform methane to $\mathrm{H}_{2}$ and $\mathrm{CO}$ after it is formed. It is interesting to compare these results to those obtained by Exxon in their CCG process.

TABLE 19. Effect of Sodium Carbonate on Carbon Conversion to Gas for Mode1 Compounds Reacted with Steam at $600^{\circ} \mathrm{C}$ (a)

\begin{tabular}{|c|c|c|c|}
\hline & Catalyst & $\begin{array}{c}\text { Feed Rate, } \\
\mathrm{g} / \mathrm{min}\end{array}$ & $\begin{array}{l}\text { Carbon Converted } \\
\text { to Gas, } \%\end{array}$ \\
\hline Methanol & $\begin{array}{l}\text { None } \\
\mathrm{Na}_{2} \mathrm{CO}_{3}\end{array}$ & $\begin{array}{l}0.46 \\
0.46\end{array}$ & $\begin{array}{r}0.8 \\
19.2\end{array}$ \\
\hline Acetic acid & $\begin{array}{l}\text { None } \\
\mathrm{Na}_{2} \mathrm{CO}_{3}\end{array}$ & $\begin{array}{l}0.53 \\
0.53\end{array}$ & $\begin{array}{r}7.2 \\
53.9\end{array}$ \\
\hline Acetal dehyde & $\begin{array}{l}\text { None } \\
\mathrm{Na}_{2} \mathrm{CO}_{3}\end{array}$ & $\begin{array}{l}\text { (b) } \\
\text { (b) }\end{array}$ & $\begin{array}{r}9.4 \\
38.3\end{array}$ \\
\hline Acetone & $\begin{array}{l}\text { None } \\
\mathrm{Na}_{2} \mathrm{CO}_{3}\end{array}$ & $\begin{array}{l}0.46 \\
0.46\end{array}$ & $\begin{array}{l}0.4 \\
0.1\end{array}$ \\
\hline
\end{tabular}

(a) Data from Hallen, Sealock, and Cuello (1982).

(b) Preliminary experiments at varied feed rates. 
Exxon found that $\mathrm{K}_{2} \mathrm{CO}_{3}$ impregnated on the coal increased the methane concentration up to the equilibrium concentration at $700^{\circ} \mathrm{C}$ and $3.6 \mathrm{MPa}$. Neither $\mathrm{K}_{2} \mathrm{CO}_{3}$ nor char alone was able to catalyze the methanation reaction, but the two in combination were catalytic (Nahas and Gallagher 1978). This is unusual, because hydrogenation catalysis does not usually involve alkalis. Cabrera, Heinemann, and Sonorjai (1982) found that methane could be formed by direct hydrogenation of graphite catalyzed with $\mathrm{K}_{2} \mathrm{CO}_{3}$ but the concentrations were 1 ow.

If alkali carbonates do in fact catalyze formation of methane, they could also be expected to catalyze the reverse reaction, steam-reforming; however, this has not been observed in the PNL studies.

SECONDARY CATALYSTS

The secondary reactions that can be catalyzed during biomass gasification are shown in Table 11. Nickel-based catalysts are the most effective for this combination of reactions.

\section{Catalytic Effects}

With an active nickel catalyst the methanation/steam-reforming reaction and the shift reaction are catalyzed to equilibrium concentrations in both the laboratory and POU gasifiers. At lower temperatures (such as $550^{\circ} \mathrm{C}$ ), nickel catalyzes the methanation reaction. At higher temperatures (such as $750^{\circ} \mathrm{C}$ ), nickel catalyzes steam-reforming of methane (pyrolysis) to hydrogen and carbon monoxide. Over the temperature range studied $\left(550\right.$ to $\left.850^{\circ} \mathrm{C}\right)$ all tar is converted to gas and/or char when active nickel catalysts are present. This may involve steam-reforming, thermal cracking, catalytic cracking, or a combination.

Rostrup-Nielson (1977) has presented the following sequence for steamreforming of naptha:

$$
\begin{aligned}
& \mathrm{C}_{n} \mathrm{H}_{\mathrm{m}}+2 \mathrm{~S} \longrightarrow \mathrm{C}_{n} \mathrm{H}_{2}-\mathrm{S}_{2}+\frac{\mathrm{ml-z}}{2} \mathrm{H}_{2} \\
& \mathrm{C}_{n z} \mathrm{H}_{2} \mathrm{~S}+\mathrm{H}_{2}+\mathrm{S}_{1} \longrightarrow \mathrm{C}_{n-1} \mathrm{H}_{2}-\mathrm{S}+\mathrm{CH}_{x}-\mathrm{S}
\end{aligned}
$$




$$
\begin{aligned}
& \mathrm{H}_{2} \mathrm{O}+\mathrm{S}=\mathrm{O}-\mathrm{S}+\mathrm{H}_{2} \\
& \mathrm{CH}_{x}-\mathrm{S}+\mathrm{O}-\mathrm{S} \longrightarrow \mathrm{CO}+\frac{\mathrm{x}}{2} \mathrm{H}_{2}+2 \mathrm{~S}
\end{aligned}
$$

where $S$ is an active site on the catalyst. The first step is chemisorption of the hydrocarbon on a dual nickel site involving dehydrogenation. This is followed by rupture of the carbon-carbon bond and formation of surface radical $\mathrm{CH}_{\mathrm{X}}$. Adsorption of steam is thought to occur on the support on the basis of the observed influence of support type on the kinetics of the reaction (Bhatta and Dixon 1969). The adsorbed stean (or oxygen) reacts with the surface radical $\mathrm{CH}_{x}$ to produce carbon monoxide and hydrogen.

At higher temperatures $\left(>700^{\circ} \mathrm{C}\right)$ cracking reactions may become significant, particularly in the presence of acidic catalysts such as zeolites, silicaalumina, and alumina. Thermal cracking proceeds via free-radical mechanisms. The initial step is the homolysis of a carbon-carbon bond to form free radicals that can continue to undergo scission to form smaller and smaller radicals (Gates, Katzer, and Schwit 1979). Catalytic cracking reactions are highly complex but can be interpreted in terms of carbonium-ion theory (Gates, Katzer, and Schuit 1979; Satterfield 1980). A carbonium ion is formed by abstraction of a proton from a Bronstad acid. The resulting carbonium ion undergoes fission and the process is repeated. Commercial catalytic cracking results in a large buildup of carbon on the catalyst that must be removed by regeneration. Mechanisms of Carbon Deposition

Reactions that can cause carbon deposition, or coking, of secondary catalysts include:

$$
\begin{aligned}
& 2 \mathrm{CO}=\mathrm{C}+\mathrm{CO}_{2} \\
& \mathrm{CH}_{4} \longrightarrow \mathrm{C}+2 \mathrm{H}_{2} \\
& \mathrm{C}_{\mathrm{n}} \mathrm{H}(\text { Tight hydrocarbons }) \longrightarrow \text { polymers } \longrightarrow \text { coke } \\
& \text { Tars } \longrightarrow \text { coke + gases }
\end{aligned}
$$


Carbon can also be removed from catalysts by gasification reactions which include the reverse of reactions 1 and 2 and the carbon/stearn reaction

$$
\mathrm{C}+\mathrm{H}_{2} \mathrm{O} \longrightarrow \mathrm{CO}+\mathrm{H}_{2}
$$

Even though the equilibrated gas may show no affinity for carbon formation, in an open themodynamic system carbon may be stable in a steady-state, and the accumulation of carbon may continue. The question of whether there is a net buildup of carbon, and subsequent deactivation, is thus a kinetic one and is influenced by the choice of catalysts (Rostrup-Nielson 1975).

Several types of carbon have been found on nickel catalysts used for steam-reforming and methanation, depending on the test conditions. (a) These are summarized in Table 20. Whisker carbon results from decomposition of $\mathrm{CO}$,

TABLE 20. Different Types of Carbon Formation in Steam-Reforming of Hydrocarbons a)

\begin{tabular}{|c|c|c|c|}
\hline & Polymer & Whisker & Pyrolytic \\
\hline Formation & $\begin{array}{l}\text { Slow polymerization } \\
\text { of hydrocarbon radi- } \\
\text { cals on nickel sur- } \\
\text { face into encapsu- } \\
\text { lating film }\end{array}$ & $\begin{array}{l}\text { Oiffusion of carbon } \\
\text { through nickel crys- } \\
\text { tal, whisker growth } \\
\text { with Ni-crystal at } \\
\text { top }\end{array}$ & $\begin{array}{l}\text { Thermal cracking of } \\
\text { hydrocarbons. Deposi- } \\
\text { tion of C precursors } \\
\text { on catalyst }\end{array}$ \\
\hline Effects & $\begin{array}{l}\text { Progressive deacti- } \\
\text { vation }\end{array}$ & $\begin{array}{l}\text { No deactivation. } \\
\text { Breakdown of cata- } \\
\text { lyst, plugging }\end{array}$ & $\begin{array}{l}\text { Encapsulation of } \\
\text { catalyst particle and } \\
\text { deactivation }\end{array}$ \\
\hline $\begin{array}{l}\text { Temperature } \\
\text { range, }{ }^{\circ} \mathrm{C}\end{array}$ & $<500$ & $>450$ & $>600$ \\
\hline $\begin{array}{l}\text { Critical } \\
\text { parameters }\end{array}$ & $\begin{array}{l}\text { Low temperature } \\
\text { Low } \mathrm{H}_{2} \mathrm{O} / \mathrm{C} \\
\text { Low } \mathrm{H}_{2} / \mathrm{C} \\
\text { Aromatics }\end{array}$ & $\begin{array}{l}\text { High temperature } \\
\text { Low } \mathrm{H}_{2} \mathrm{O} / \mathrm{C}\end{array}$ & $\begin{array}{l}\text { High temperature } \\
\text { Low } \mathrm{H}_{2} \mathrm{O} / \mathrm{C} \\
\text { High pressure } \\
\text { Acjdity of catalyst }\end{array}$ \\
\hline
\end{tabular}

(a) Oata from Rostrup-Nielson (1982).

(a) Rostrup-Nielson 1982; Rostrup-Nielson and Trimm 1977; Trimm 1977; McCarty et al. 1981. 
$\mathrm{CH}_{4}$, and heavier hydrocarbons. Polymer and pyrolytic carbon generally occur only with heavier hydrocarbon feeds.

In steam-reforming of hydrocarbons at low temperatures, coking usually takes the form of progressive deactivation by polymer formation on the nickel surfaces. For a given set of conditions, feedstocks, and catalyst there is a temperature above which this type of coking will not occur.

At higher temperatures (above $450^{\circ} \mathrm{C}$ ) whisker carbon formation predominates. Above $530^{\circ} \mathrm{C}$ the whiskers become more like layers. These types of carbon can accumulate quite rapidly and in large amounts. At a given set of conditions (temperature, feedstock, catalyst) there is a critical steam/carbon ratio below which whisker carbon will occur. At temperatures above $600^{\circ} \mathrm{C}$, thermal cracking and coke formation on the catalyst may occur. Acidic catalyst surfaces are more susceptible to this type of coking.

Polymer carbon deposition results in progressive deactivation. Whisker carbon growth does not cause the loss of intrinsic catalyst activity, but can cause deactivation when the whiskers block the pores. Pyrolytic carbon deposition occurs on the catalyst surface and also causes deactivation by pore blockage.

High-Temperature Coking. Laboratory studies were initiated with various model compounds to determine the cause of carbon deposition. The four feeds tested were a $50 / 50 \mathrm{H}_{2} / \mathrm{CO}$ mixture, methane, ethylene, and phenol to represent reactions 1 through 4 . The results at $750^{\circ} \mathrm{C}$ with a $\mathrm{NiCuMo} / \mathrm{SiO}_{2}-\mathrm{Al}_{2} \mathrm{O}_{3}$ catalyst are shown in Table 21. Very $1 \mathrm{ittle}$ carbon was formed with the $\mathrm{H}_{2} / \mathrm{CO}$ mixture or with methane. Coking was more severe with ethylene and phenol, indicating that reactions 3 and 4 are primarily responsible for the carbon deposition. These results are similar to those obtained for steam-reforming various hydrocarbons where the relative rate of carbon formation was as follows (Satterfield 1980):

\footnotetext{
Ethylene > benzene, toluene > heptane > hexane > cyclohexane $>$ butane a carbon monoxide > methane
} 
TABLE 21. Effect of Feed on Carbon Deposition (a)

\begin{tabular}{lc}
\multicolumn{1}{c}{ Feed } & $\begin{array}{c}\text { wt\% Carbon on Catalyst } \\
\text { After } 4 \text { hours }\end{array}$ \\
\cline { 2 - 2 } CO/H2 $(50 / 50)$ & 0.1 \\
Methane & 1.3 \\
Ethylene & 6.4 \\
Phenol & 6.3
\end{tabular}

(a) $\mathrm{NiCuMo} / \mathrm{SiO}_{2}-\mathrm{Al}_{2} \mathrm{O}_{3}$ catalyst, $750^{\circ} \mathrm{C}$, $\sim 3$ moles $\mathrm{H}_{2} \mathrm{O} /$ mole $\mathrm{C}$.

A scanning electron microscopy (SEM) micrograph of a catalyst coked at $750^{\circ} \mathrm{C}$ in a laboratory gasification test (Figure 11) shows a $\mathrm{film}$ of amorphous carbon on the catalyst, but whisker growths like those shown by McCarty et al. (1981) and Albright, McConnell and Welther (1979) are not apparent. The conclusion from the gas phase reactor studies and the SEM studies is that cracking of hydrocarbons is the primary cause of carbon deposition.

Several other variables were tested to determine their effect on carbon depositon: steam rate, temperature, catalyst support, bimetallic combinations with nickel, and addition of alkal $i$ to the catalyst. Of these variables, the type of catalyst support had the most significant effect on coking, as shown in Table 22. A cominercial steam-reforming catalyst, G-90C, nickel-supported on a-alumina, had the lowest amount of carbon deposition both with wood in laboratory gasification tests and with phenol in model compound studies. The other, more acidic supports had more carbon deposition. These results reinforce the conclusion that cracking of tars on the support is the predominant cause of carbon deposition.

Wen (1983) found that petroleum catalytic cracking catalysts were effective in converting coal tar to chars and gases in the temperature range of 350 to $500^{\circ} \mathrm{C}$. Carbon buildup on the catalysts was quite rapid and the catalyst effectiveness decreased very rapidly if the coke was not removed. 




FIGURE 11. SEM Micrograph of Catalyst Coked at $750^{\circ} \mathrm{C}$

TABLE 22. Effect of Catalyst Support on Carbon Deposition at $750^{\circ} \mathrm{C}$

\begin{tabular}{|c|c|c|}
\hline \multirow[b]{2}{*}{ Catalyst Support } & \multicolumn{2}{|c|}{ wt\% C on the Catalyst } \\
\hline & Wood (a) & Phenol (b) \\
\hline$\alpha-\mathrm{Al}_{2} \mathrm{O}_{3}$ & 0.1 & 0.4 \\
\hline $\mathrm{SiO}_{2}-\mathrm{Al}_{2} \mathrm{O}_{3}$ & 2 to 7 & 6.3 \\
\hline $\mathrm{SiO}_{2}-\mathrm{Al}_{2} \mathrm{O}_{3}$ (y-zeolite $)$ & - & 15 \\
\hline $\mathrm{Y}-\mathrm{Al}_{2} \mathrm{O}_{3}$ & 21,20 & 20 \\
\hline
\end{tabular}

(a) Gasification tests in a laboratory gasifier, various exposure times.

(b) After 4 to 5 hours exposure.

In the Syntar process being developed by the Ralph M. Parsons Company, coal tar is reacted with steam in the presence of catalysts at about $600^{\circ} \mathrm{C}$ to produce fuel gases. Catalysts with acidic supports were found to be susceptible to coking (Stern 1982). 
Increasing the temperature from 750 to $850^{\circ} \mathrm{C}$ reduced carbon deposition. This effect is similar to the results of Ekstrom, Lindman, and Petterson (1982) with secondary catalysts in the MINO process. Carbon deposition increased at $650^{\circ} \mathrm{C}$ but not dramatically.

Use of trimetallic or alloy catalysts (NiCuMo or NiCoMo) also appears to reduce carbon deposition in gasification tests. A similar effect has been observed in steam-reforming tests, but it was attributed to the lower adsorption rate and lower activity of the catalyst. The trimetallic catalysts used for gasification were quite active. A NiCoMo/ $\mathrm{SiO}_{2}-\mathrm{Al}_{2} \mathrm{O}_{3}$ catalyst ran for over 1000 hours in the laboratory gasifier at $750^{\circ} \mathrm{C}$ and retained its activity for converting tars and for the water-gas shift reaction. Its activity for methane-reforming was reduced significantly in the first 100 hours, but no additional loss of activity was noted thereafter. After 100 hours the catalyst had accumulated $7 \mathrm{wt} \%$ carbon; however, by the end of the run only $4 \mathrm{wt} \%$ remained.

Work on methanation reactions with a $\mathrm{NiCu}$ bimetallic catalyst demonstrated that copper dilutes the nickel sites, thus inhibiting carbon formation (Araki and Ponec 1976). A bimetallic NiCu catalyst shows higher rates for cyclohexane dehydrogenation than does pure nickel. Some investigators have attributed this effect to less carbon fouling of the bimetallic surface compared to the pure metal (Cusumano, Dalla Betta, and Levy 1978).

Limited PDU data indicate that coking on the $\mathrm{NiCuMo} / \mathrm{SiO}_{2}-\mathrm{Al}_{2} \mathrm{O}_{3}$ catalyst may be much more severe than was experienced in the laboratory gasifier. In the gas-phase reactor studies, carbon deposition was similar to that experienced in the laboratory gasifier (as shown in Table 22) except at low steam rates with phenol, where coking was quite substantial. Schafizadeh and Fu (1973) and Milne, Evans, and Solty (1983) have concluded that tar is the primary product of pyrolysis at high temperatures and that a large percentage of the gases and char produced at high temperatures is formed from secondary reactions of tar. This tar is very reactive and likely to form carbon (much of the tar is converted to gases and char even without a catalyst present). At $750^{\circ} \mathrm{C}$ in the laboratory the secondary reactions of tar take place before the product gas contacts the catalyst and coking on the catalyst is 1 imited. In the PDU 
the primary tar contacts the catalyst immediately and the large quantity of tar produced results in a low steam/tar ratio. This may produce the same effect as did the reduction of the steam/phenol ratio in the model compound studies discussed eartier.

The increased coking at low steam rates may be the result of increased coking from thermal cracking or it may be that the steam/tar (phenol) ratio has dropped below the critical ratio for whisker carbon formation. Rapid whisker carbon formation can physically break down the catalyst (Rostrup-Nielson 1982). If this type of carbon is formed in PDU operations it may explain the high attrition rate noted in the PDU.

If the increased coking is due to themal cracking on the support, catalysts with non-acidic supports, such as $G-90 C$, should be effective. Doping with alkali or using magnesia-supported catalysts should also reduce coking. Alkali reduces the acidity of supports and increases steam adsorption on the support, thereby increasing the rate of carbon gasification. Tests on the effect of doping nickel catalysts with alkali in laboratory gasification studies have produced inconclusive results. In addition, alkalis will be fairly mobile at $750^{\circ} \mathrm{C}$ and will eventually be lost. Magnesia supports have also enhanced adsorption and have been used successfully for naptha steam-reforming.

If the increased coking is due to whisker carbon growth the solution may be more difficult. Raising the steam rate affects the product gas composition so there is little flexibility in adjusting the steam/tar ratio. Doping with alkali or using magnesia-supported catalysts should help; however, their effects are limited. Placing the catalyst in a secondary reactor and allowing the secondary tar reactions to take place in the gasifier should solve the problem. This is essentially what happens in the laboratory gasification system, where long catalyst 1 ifetimes have been demonstrated.

Low-Temperature Coking $\left(550^{\circ} \mathrm{C}\right)$. At lower temperatures more favorable to the production of methane-rich gas, pyrolysis or cracking on the support is probably not significant (Rostrup-Nielson 1975, 1982; Trimm 1977). However, carbon deposition is considerably more severe than at $750^{\circ} \mathrm{C}$, suggesting that a different mechanism for carbon deposition may be involved. In this lower temperature range whisker carbon formation is suspected to be the major type of 
carbon deposition. SEM studies of catalysts used at $550^{\circ} \mathrm{C}$ are planned to verify this conclusion. If whisker carbon growth is the cause the only solution would appear to be to significantly increase the steam rate. This may not be economic in terms of the process, however, because additional steam will cost more and will reduce the equilibrium yield of methane. 


\section{REFERENCES}

Albright, L. F., C. F. McConnell, and K. Welther. 1979. "Types of Coke Formed During Pyrolysis of Light Hydrocarbons." Am. Chem. Soc. Adv. Chem. Ser. 183: 175-191.

Anonymous. 1983. "French Fertilizer Manufacturer Testing New Biomass-Gasification Process." Chem. Eng., May 16, p. 17.

Araki, M., and V. Ponec, 1976. "Methanation of Carbon Monoxide on Nickel and Nickel Copper Alloys." J. Catalysis 44:439-448.

Baker, E. G., and M. D. Brown. 1984. Catalytic Gasification of Bagasse for the Production of Methanol. PNL-5100, Pacific Northwest Laboratory, Richland, Washington.

Baker, E. G., et al. 1983. "Methanol Synthesis Gas from Wood Gasification." Energy Progress 3(4):226-229.

Bhatta, K. S. M., and G. M. Dixon. 1969. Ind. Eng. Chem. Prod. Res. Dev. $8: 324$.

Cabrera, A. L, H. Heinemann, and G. A. Somorjai. 1982. J. Catalysis 75:7.

Cox, J. L., and L. J. Sealock, Jr. 1974. "Sulfur Problems in the Direct Catalytic Production of Methane from Coal-Steam Reactions." Prepr. Am. Chem. Soc. Div. Fuel Chem. 19(1):64-78.

Cusumano, J. A., R. A. Dalla Betta, and R. B. Levy. 1978. Catalysis in Coal Conversion. Academic Press, New York.

Ekstrom, C., N. Lindman, and R. Pettersson. 1982. "Catalytic Conversion of Tars, Carbon Black, and Methane from Pyrolysis/Gasification of Biomass." Presented at The Fundamentals of Themochemical Biomass Conversion Conference, october 19-22, Estes Park, Colorado.

Fant, B. T., and C. A. Euker, Jr. 1980. "Exxon's Catalytic Coal Gasification Process." Proceedings of the First International Research Conference. Gas Research Institute, Chicago, Illinois.

Furlong, L. E., and N. C. Nahas. 1978. "Catalytic Coal Gasification - Process Research and Development." Proceedings of the Tenth Synthetic Pipeline Symposium. Gas Research Institute, Chicago, Ininois.

Gates, B. C., J. R. Katzer, and G. C. A. Schuit. 1979. Chemistry of Catalytic Processes. McGraw-Hi11, New York.

Gregg, S. J. 1965. The Surface Chemistry of Solids. Chapman and Ha11, London. 
Hallen, R. T., L. J. Sealock, and R. Cuello. 1982. "Influence of Alkali Carbonates on Biomass Volatilization." Presented at The Fundamentals of Thermochemical Biomass Conversion Conference, October 18-22, Estes Park, Colorado.

Hawley, M. C., et al. 1983. "Gasification of Wood Char and Effects of Intraparticle Transport." Fuel 62:213-216.

Haynes, W. P., S. J. Gasior, and A. J. Forney. 1974. "Catalysis of Coal Gasification at Elevated Pressure." Am. Chem. Soc. Adv. Chem. Ser. 131:179.

Hoffman, E. J., et al. 1972. "Behavior of Nickel Methanation Catalysts in Coal-Steam Reactions." Am. Chem. Soc. Div. Fuel Chem. Prepr. 16(2):64-67.

Kono, H. 1980. "A New Concept for Three-Phase Fluidized Beds." Hydrocarbon Processing. January, pp. 123-129.

Kosky, P. G., et al. 1982. Coal Gasification Catalysis Mechanisms. DOE/MC/14591-1397, General Electric Company, Schenectady, New York.

Lindman, N., et a1. 1981. "A New Synthesis Gas Process for Biomass and Peat." Proceedings of the Fifth Energy from Biomass and Wastes Symposium, Institute of Gas Technology, Chicago, ITTinois.

Marschner, F., and H. J. Renner. 1982. "Naphtha Reforming." Hydrocarbon Processing, April, pp. 176-180.

McCarty, J. G., et al. 1981. Hydrocarbon Reforming for Hydrogen Fuel Cells. DOE/MC/11323-T2. SRI InternationaT, MenTo Park, CaTifornia.

McCoy, L. R. 1983. Investigations of Coal Gasification Catalysis Reaction Mechanisms. D0E/MC714592-1419. Energy Systems Research Group, Albany, New York, and Rockwell International Corporation, Thousand Oaks, California.

Mckee, D. W. 1983. "Mechanisms of Alkali Metal Catalyzed Gasification of Carbon." Fuel 62(2):170-175.

Mckee, 0. W., et a1. 1983. "Catalysis of Coal Char Gasification by Alkali Metal Salts." Fuel 62(2):217-220.

Milne, T. A., R. J. Evans, and S. Solty. 1983. Fundamental Pyrolysis Studies, Quarterly Report March - May. Solar Energy Research Institute, Golden, Colorado.

Mitche11, D. H., et al. 1980. "Methane/Methanol by Catalytic Gasification of Biomass." Chem. Eng. Prog. 76(9):53-57.

Mudge, L. K., L. J. Sealock, Jr., and S. L. Weber. 1979. "Catalyzed Steam Gasification of Biomass." J.Anal. Appl. Pyrolys is 1:165-175. 
Mudge, L. K., et a1. 1981. Investigations on Catalyzed Steam Gasification of $B$ iomass (Including Appendices $A, B, C$, and D), PNL-3695, Pacific Northwest Laboratory, Richland, Washington.

Mudge, L. K., et al. 1983. Catalytic Gasification Studies in a Pressurized Fluid Bed Unit. PNL-4594, Pacific Northwest Laboratory, Richland, Washington.

Nahas, N. C., and J. E. Gallagher. 1978. Proc. 13th Energy Conv. Eng. Conf. $3: 2143$.

Nahas, N. C. 1983. "Exxon Catalytic Coal Gasification Process." Fuel $62(2): 239-241$.

Pederson, K., A. Skov, and J. R. Rostrup-Nielson. 1980. "Catalytic Aspects of High Temperature Methanation." Prepr. Am. Chem. Soc. Div. Fue1 Chem. 25(2):89-99.

Ross, R. A., and P. Fong. 1981. "Catalytic Conversion of Wood Barks to Fuel Gas." Ind. Eng. Chem. Prod. Res. Dev. 20:197-203.

Rostrup-Nielson, J. R. 1975. Steam Reforming Catalysts. Danish Technical Press, Copenhagen.

Rostrup-Nielson, J. R. 1977. "Hydrogen via Steam Reforming of Naptha." Chem. Eng. Prog. 73:87-92.

Rostrup-Nielson, J. R. 1982. "Criteria for Carbon Formation." NATO Adv. Study Inst. Ser., Series E, 54:127-149.

Rostrup-Nielson, J. R., and D. L. Trimm. 1977. "Mechanisms of Carbon Formation on Nickel-Containing Catalysts." J. Catalysis, 48:155-165.

Satterfield, C. N. 1980. Heterogeneous Catalysis in Practice. McGraw $\rightarrow$ Hill, New York.

Sealock, L. J., et al. 1981. Kinetics and Catalysis of Producing Synthetic Gases from Biomass. Annual Report. GRI-80/0116, Battelle, Pacific Northwest Laboratories, Richland, Washington.

Sealock, L. J., D. C. Elliott, and R. T. Hallen. 1982. Kinetics and Catalysis of Producing Synthetic Gases from Biomass. Final Report. GRI-82/0038, Battelle, Pacific Northwest Laboratories, Richland, Washington.

Schafizadeh, F., and Y. L. Fu. 1973. "Pyrolysis of Cellulose." Carbohyd. Res. 29:113.

Schafizadeh, F. 1982. "Introduction to Pyrolysis of Biomass." J. Anal. Appl. Pyrolysis 3:283. 
Stern, E. W. 1982. Bench-Scale Development of Catalysts for Reforming Aromatic and Heterocyclic Hydrocarbons. DOE/ET/11029-1191, Englehard Corporation, Edison, New Jersey.

Taylor, H. S., and H. A. Neville. 1921. J. Am. Chem. Soc. 43:2065.

Thomas, C. L. 1979. Catalytic Processes and Proven Catalysts. Academic Press, New York.

Tran, D. Q., and C. Raj. 1978. "A Kinetic Model for Pyrolysis of Douglas Fir Bark." Fuel 57:293-298.

Trimm, D. L. 1977. "Formation and Removal of Coke from Nickel Catalysts." Catal. Rev.-Sci. Eng. 16:155-189.

Venuto, P. B., and E. T. Habib, Jr. 1979. Fluid Catalytic Cracking with Zeolite Catalysts. Marcel Dekker, New York.

Veraa, M. J., and A. T. Be11. 1978. "Effect of Alkali Hetal Catalysts on Gasification of Coal Char." Fuel 57:194-200.

Walker, P. L., et al. 1983. "Catalysis of Coal-Derived Cokes and Chars." Fuel 62(2):140-149.

Wen, W. Y. 1980. "Mechanisms of Alkali Metal Catalysis in the Gasification of Coal, Char, or Graphite." Catal. Rev.-Sci. Eng. 22(1):1-28.

Wen, H. Y. 1983. Thermal and Catalytic Cracking of Tars and Tar Constituents from Coal Gasifjcation Processes. DUE/MC/14385-1484, CTark Jniversity, Worcester, Massachusetts.

Wen, C. Y., and S. Dutta. 1978. "Research Needs for the Analysis, Design, and Scãle-up of Fluidized Beds." AIChE Symposium Series 161(73):1-8.

Willson, H. G., et al. 1974. "Alkali Carbonate and Nickel Catalysis of CoalSteam Gasification." Ann. Chen. Soc. Adv. Chem. Ser. 131:203.

Winter, E. M., N. D. Malcosky, and C. C. Hong. 1982. Catalytic Enhancement of Coal Gasification. DOE/ET/11027-1303, Columbia Gas Systems, Columbus, Ohio.

Hood, B. J., et al. 1983. The Mechanisms of Catalytic Gasification of Coal Char. DOE/MC/14593-1416, SRI International, Menlo Park, California.

Yamazaki, K., et al. 1983. "Catalytic Gasification of Wood for Methanol Synthesis Gas." Chemistry Letters 1029-1032.

Yokayama, S., et al. 1983. "Efficient Gasification of Cellulose for the Production of Hydrogen and Carbon Monoxide." Chemistry Letters 151-154. 


\section{APPENDIX A}

GAS-PHASE REACTOR STUDIES WITH SECONDARY CATALYSTS 


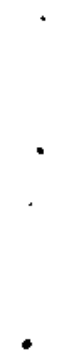


TABLE A.1. Results of Fixed-Bed Gas-Phase Reactor Studies

\begin{tabular}{|c|c|c|c|c|c|c|c|c|c|c|c|}
\hline Run & Date & Catalyst & Feed & $\begin{array}{c}\text { Temperature, } \\
{ }^{\circ} \mathrm{C} \\
\end{array}$ & $\begin{array}{l}\text { Space Velocity, } \\
\left.\text { vol.[feed }+\mathrm{H}_{2} \mathrm{O}\right] \\
\text { [h]lvol. cat.] }\end{array}$ & gteam & $\begin{array}{l}\text { Moles Steam } \\
\text { Noles Carbon }\end{array}$ & $\begin{array}{c}\text { tx } \\
\text { Carbon on Catalyst }\end{array}$ & E Converted & Enconverted & I char \\
\hline 1 & $1-5$ & $\mathrm{NiClMo} / \mathrm{SiO}_{2}-\mathrm{Al}_{2} \mathrm{O}_{3}$ & $\mathrm{CH}_{4}$ & 750 & 2540 & 2.9 & 2.6 & 1.3 & 89 & 10 & 1 \\
\hline 2 & $7-6$ & $=$ (SMR-2) & $\mathrm{CH}_{4}$ & 750 & $2160 / 4130$ & $5.6 / 5.8$ & $5.0 / 5.1$ & 1.1 & 97 & 1 & 2 \\
\hline 3 & $1-6$ & & $\mathrm{C}_{2} \mathrm{H}_{4}$ & 750 & 2170 & 3.6 & 2.8 & 6.4 & 91 & 0 & 9 \\
\hline 4 & $1-18$ & & phenol & 750 & 1980 & 6.7 & 5.8 & 3.4 & 96 & 0 & 4 \\
\hline 5 & $1-7$ & & $\mathrm{CO} / \mathrm{H}_{2}$ & 750 & 3120 & 1.8 & 2.8 & 0.1 & -- & - & -- \\
\hline 6 & $4-27$ & & $\mathrm{CH}_{4}$ & 650 & $1710 / 2410$ & $4.3 / 3.9$ & $3.8 / 3.4$ & 0.06 & 98 & 2 & 0 \\
\hline 7 & $5-3$ & & $\mathrm{CH}_{4}$ & 550 & $2200 / 2410$ & $5.9 / 3.9$ & $4.8 / 3.4$ & 0.16 & 34 & 66 & 0 \\
\hline 8 & $5-18$ & $\begin{array}{l}\text { (previously used } \\
\text { for } \mathrm{C}_{2} \mathrm{H}_{4} \text { run } 3 \text { ) }\end{array}$ & $\mathrm{CH}_{4}$ & 750 & $2520 / 2680$ & $6.0 / 4.0$ & $5.3 / 3.6$ & 3.9 & 100 & 0 & 0 \\
\hline 9 & $7-8$ & & phenol & 750 & $1900 / 3520 / 5560$ & $5.3 / 5.0 / 5.1$ & $4.7 / 4.4 / 4.5$ & $6.3-$ & $94 / 94 / 89$ & $<1 /$ trace $/ 5$ & $6 / 6 / 6$ \\
\hline 10 & $7-13$ & & phenol & $650 / 550$ & 1900 & 5.1 & 4.4 & 5.5 & $92 / 84$ & $0.5 /$ trace & $7 / 16$ \\
\hline 11 & $7-29$ & $\begin{array}{l}\text { \{previously used } \\
\text { for phenol run } \\
9\}\end{array}$ & $\mathrm{CH}_{4}$ & 750 & 2210 & 5.2 & 4.6 & 4.3- & 88 & 2 & 10 \\
\hline 12 & $8-5$ & & $\mathrm{CH}_{4} /$ phenol & 750 & 1940 & 2.8 & 2.5 & - & 94 & 0 & 6 \\
\hline 13 & $8-8$ & & $\mathrm{CH}_{4} /$ phenol & 750 & 1960 & 2.8 & 2.4 & $\infty$ & 95 & 0.4 & 4 \\
\hline 14 & $8-9$ & & $\mathrm{CH}_{4} /$ phenol & 750 & 2070 & 2.4 & 2.1 & 17.2 & 90 & 3 & 7 \\
\hline 15 & $9-2$ & & $\mathrm{CH}_{4} /$ phenol & 750 & 10,680 & 3.0 & 2.6 & 12.6 & 26 & 65 & 9 \\
\hline 16 & $9-8$ & & phenol & 750 & 4320 & 1.3 & 1.2 & 22.4 & 17 & 77 & 6 \\
\hline 17 & $9-13$ & & phenol & 750 & 1130 & 1.4 & 1.2 & 18.9 & 28 & 53 & 19 \\
\hline 18 & $9-21$ & $\begin{array}{l}(\text { doped with } 2 \text { wty } \\
\left.\mathrm{Ha}_{2} \mathrm{CO}_{3}\right)\end{array}$ & phenol & 750 & 2110 & 6.5 & 5.7 & 1.2 & 97 & 2 & 1 \\
\hline 19 & $9-23$ & & phenol & 750 & 2350 & 4.2 & 3.7 & 0.4 & 98 & 0.4 & 1.5 \\
\hline 20 & $9-27$ & (crushed) & phenol & 750 & 2430 & 4.2 & 3.6 & 1.6 & 98 & 0.5 & 1.2 \\
\hline
\end{tabular}


TABLE A.1. (contd)




APPENDIX B

DATA FROM FIXED-BED LABORATORY TESTS 
TABLE B.1. Results of Primary Catalyst Tests in Continuous Laboratory Reactor

\begin{tabular}{|c|c|c|c|c|c|c|c|c|c|c|c|c|c|}
\hline \multirow[b]{2}{*}{ Run } & \multirow{2}{*}{$\begin{array}{c}\text { Temperature, } \\
{ }^{\circ} \mathrm{C} \\
\end{array}$} & \multirow{2}{*}{$\begin{array}{c}\text { wt } \\
\text { Steam/ } \\
\text { wt } \\
\text { Wood } \\
\end{array}$} & \multirow{2}{*}{$\begin{array}{c}\text { Catalyst } \\
\text { and } \\
\text { Loading, } \\
\text { wt\% }\end{array}$} & \multirow{2}{*}{$\begin{array}{l}\text { Residence } \\
\text { Time, min } \\
\end{array}$} & \multicolumn{6}{|c|}{ Gas Composition } & \multicolumn{3}{|c|}{ Carbon Conversjon } \\
\hline & & & & & $\underline{\mathrm{H}_{2}}$ & $\mathrm{CO}_{2}$ & $\mathrm{CH}_{4}$ & $\mathrm{C}_{2} \mathrm{H}_{4}$ & $\mathrm{C}_{2} \mathrm{H}_{6}$ & $\mathrm{CO}$ & Gas & Char & $\operatorname{Tar}^{(2)}$ \\
\hline $1 \mathrm{~A}$ & 750 & 1.0 & -- & 55 & 46 & 26 & 7.1 & 1.6 & 0.5 & 19 & 80 & 16 & 4 \\
\hline 3 & 750 & 0.9 & $17 \mathrm{~K}_{2} \mathrm{CO}_{3}$ & 18 & 52 & 25 & 5.4 & 1.0 & 0.6 & 15 & 73 & 27 & 0.1 \\
\hline 4 & 750 & 1.0 & $17 \mathrm{~K}_{2}^{2} \mathrm{CO}_{3}$ & 11 & 52 & 25 & 5.2 & 1.0 & 0.6 & 15 & 70 & 30 & $\operatorname{tr}$ \\
\hline $4 A$ & 750 & 0.9 & $17 \mathrm{~K}_{2}^{2} \mathrm{CO}_{3}$ & 34 & 53 & 24 & 5.1 & 1.0 & 0.5 & 17 & 77 & 23 & $\operatorname{tr}$ \\
\hline 5 & 750 & 1.1 & $13 \mathrm{Na}_{2} \mathrm{CO}_{3}$ & 50 & 51 & 26 & 5.9 & 1.0 & 0.6 & 16 & 73 & 27 & $\operatorname{tr}$ \\
\hline 6 & 750 & 1.0 & $13 \mathrm{Na}_{2} \mathrm{CO}_{3}$ & 17 & 50 & 25 & 6.3 & 1.1 & 0.7 & 16 & 66 & 34 & tr \\
\hline 9 & 750 & 1.1 & $8.5 \mathrm{~K}_{3} \mathrm{CO}_{3}$ & 21 & 53 & 27 & 5.3 & 1.0 & 0.5 & 14 & 69 & 31 & $\operatorname{tr}$ \\
\hline 11 & 750 & 1.2 & $8.5 \mathrm{~K}_{3} \mathrm{CO}_{3}$ & 24 & 54 & 24 & 4.3 & 0.8 & 0.4 & 17 & 85 & 15 & $\operatorname{tr}$ \\
\hline 12 & 750 & 1.1 & $8.5 \mathrm{~K}_{2} \mathrm{CO}_{3}$ & 7 & 51 & 27 & 6.6 & 1.2 & 0.6 & 14 & 65 & 35 & $\mathrm{tr}$ \\
\hline 13 & 750 & 1.1 & $8.5 \mathrm{~K}_{2} \mathrm{CO}_{3}$ & 50 & 53 & 25 & 4.4 & 0.9 & 0.5 & 17 & 83 & 17 & $\operatorname{tr}$ \\
\hline 16 & 750 & 1.1 & $6.5 \mathrm{Na}_{2} \mathrm{CO}_{3}$ & 49 & 55 & 24 & 5.3 & 0.8 & 0.3 & 14 & 84 & 16 & $\operatorname{tr}$ \\
\hline 17 & 750 & 1.2 & $6.5 \mathrm{Na}_{2} \mathrm{CO}_{3}$ & 49 & 54 & 26 & 6.1 & 1.0 & 0.5 & 13 & 71 & 29 & $\operatorname{tr}$ \\
\hline 18 & 750 & 1.2 & $6.5 \mathrm{Na}_{2} \mathrm{CO}_{3}$ & 10 & 52 & 27 & 6.6 & 1.1 & 0.5 & 12 & 66 & 34 & $\operatorname{tr}$ \\
\hline 19 & 750 & 1.1 & $6.5 \mathrm{Na}_{2} \mathrm{CO}_{3}$ & 21 & 53 & 26 & 5.8 & 1.0 & 0.5 & 14 & 72 & 28 & $\operatorname{tr}$ \\
\hline 20 & 750 & 1.3 & -- & 15 & 39 & 29 & 10.9 & 2.4 & 0.9 & 18 & 57 & 32 & 11 \\
\hline 21 & 750 & 1.2 & -- & 4 & 37 & 28 & 11.9 & 2.5 & 0.6 & 20 & 47 & 42 & 11 \\
\hline 22 & 750 & 1.7 & -- & 29 & 45 & 26 & 9.3 & 2.0 & 0.5 & 17 & 68 & 27 & $5^{(b)}$ \\
\hline 23 & 750 & 4.0 & $17 \mathrm{~K}_{2} \mathrm{CO}_{3}$ & 10 & 56 & 31 & 5.3 & 1.2 & 0.3 & 7 & 71 & 29 & tr \\
\hline 24 & 750 & 4.3 & $17 \mathrm{~K}_{2} \mathrm{CO}_{3}$ & 24 & 58 & 29 & 4.6 & 1.0 & 0.3 & 7 & 84 & 16 & $\operatorname{tr}$ \\
\hline 25 & 750 & 3.7 & $17 \mathrm{~K}_{2} \mathrm{CO}_{3}$ & 18 & 59 & 29 & 4.3 & 1.0 & 0.3 & 7 & 80 & 20 & $\operatorname{tr}$ \\
\hline 26 & 750 & 1.1 & $17 \mathrm{~K}_{2} \mathrm{CO}_{3}$ & 82 & 54 & 24 & 4.9 & 1.0 & 0.4 & 15 & 81 & 19 & $\operatorname{tr}$ \\
\hline 27 & 750 & 0.6 & $17 \mathrm{~K}_{2}^{2} \mathrm{CO}_{3}$ & 26 & 51 & 17 & 4.3 & 0.7 & 0.5 & 26 & 83 & 17 & $\operatorname{tr}$ \\
\hline 28 & 750 & 0.6 & $17 \mathrm{~K}_{2} \mathrm{CO}_{3}$ & 34 & 52 & 20 & 5.5 & 1.0 & 0.4 & 21 & 72 & 28 & $\operatorname{tr}$ \\
\hline 29 & 650 & 1.1 & $17 \mathrm{~K}_{2} \mathrm{CO}_{3}$ & 213 & 57 & 26 & 4.3 & 0.4 & 0.5 & 11 & 61 & 37 & 2 \\
\hline 30 & 650 & 1.0 & $17 \mathrm{~K}_{2} \mathrm{CO}_{3}$ & 108 & 55 & 27 & 5.0 & 0.6 & 0.6 & 11 & 52 & 48 & 1 \\
\hline & 650 & 1.2 & $17 \mathrm{~K}_{2}^{2} \mathrm{CO}_{3}$ & 82 & 31 & 40 & 8.6 & 1.5 & 1.0 & 18 & 28 & 63 & 9 \\
\hline $32^{(c)}$ & 750 & 1.5 & $17 \mathrm{~K}_{2}^{2} \mathrm{CO}_{3}$ & 16 & 52 & 30 & 7.2 & 1.7 & 0.6 & 9 & 52 & 48 & $\operatorname{tr}$ \\
\hline 33 & 750 & 1.0 & $17 \mathrm{~K}_{2} \mathrm{CO}_{3}$ & 12 & 48 & 28 & 7.6 & 1.7 & 0.5 & 13 & 50 & 50 & $\operatorname{tr}$ \\
\hline
\end{tabular}


TABLE B.1. (contd)

\begin{tabular}{|c|c|c|c|c|c|c|c|c|c|c|c|c|c|}
\hline \multirow[b]{2}{*}{ Run } & \multirow{2}{*}{$\begin{array}{c}\text { Temperature, } \\
{ }^{\circ} \mathrm{C}\end{array}$} & \multirow{2}{*}{$\begin{array}{c}\text { wt } \\
\text { Steam/ } \\
\text { wt } \\
\text { Wood }\end{array}$} & \multirow{2}{*}{$\begin{array}{c}\text { Catalyst } \\
\text { and } \\
\text { Loading, } \\
\text { wto }\end{array}$} & \multirow{2}{*}{$\begin{array}{l}\text { Residence } \\
\text { Time, min }\end{array}$} & \multicolumn{6}{|c|}{ Gas Composition } & \multicolumn{3}{|c|}{ Carbon Conversjon } \\
\hline & & & & & $\mathrm{H}_{2}$ & $\mathrm{CO}_{2}$ & $\mathrm{CH}_{4}$ & $\mathrm{C}_{2} \mathrm{H}_{4}$ & $\mathrm{C}_{2} \mathrm{H}_{6}$ & $\overline{\mathrm{CO}}$ & $\overline{\mathrm{Gas}}$ & Char & $\operatorname{Tar}(a)$ \\
\hline & 750 & 1.3 & $17 \mathrm{~K}_{2} \mathrm{CO}_{3}$ & 13 & 57 & 22 & 2.9 & 0.7 & 0.4 & 17 & 79 & 21 & tr \\
\hline $35^{(c)}$ & 750 & 1.0 & $17 \mathrm{~K}_{2} \mathrm{CO}_{3}$ & 65 & 56 & 23 & 3.2 & 0.7 & 0.4 & 17 & 86 & 14 & tr \\
\hline $36^{(c)}$ & 750 & 0.7 & $17 \mathrm{~K}_{2} \mathrm{CO}_{3}$ & 167 & 56 & 17 & 1.7 & 0.6 & 0.3 & 24 & 81 & 19 & $\operatorname{tr}$ \\
\hline & 750 & 0.8 & $17 \mathrm{~K}_{2}^{2} \mathrm{CO}_{3}$ & 44 & 55 & 18 & 2.4 & 0.9 & 0.5 & 23 & 80 & 20 & $\operatorname{tr}$ \\
\hline $39^{(c)}$ & 750 & 1.1 & $8.5 \mathrm{~K}_{2} \mathrm{CO}_{3}$ & 24 & 47 & 28 & 4.1 & 1.6 & 0.8 & 18 & 60 & 40 & $\operatorname{tr}$ \\
\hline $40^{(c)}$ & 650 & 0.9 & $8.5 \mathrm{~K}_{2} \mathrm{CO}_{3}$ & 288 & 54 & 28 & 5.1 & 0.7 & 0.6 & 13 & 63 & 35 & 2 \\
\hline $41(c)$ & 650 & 1.0 & $8.5 \mathrm{~K}_{2} \mathrm{CO}_{3}^{2}$ & 19 & 50 & 29 & 7.1 & 1.1 & 1.1 & 12 & 50 & 50 & $\operatorname{tr}$ \\
\hline 42 & 750 & -- & $8.5 \mathrm{~K}_{2} \mathrm{CO}_{3}$ & 103 & 38 & 15 & 10.0 & 1.8 & 1.3 & 34 & 54 & 45 & 1 \\
\hline 43 & 750 & -- & -- & 167 & 19 & 14 & 17.4 & 3.8 & 1.4 & 45 & 39 & 52 & 11 \\
\hline
\end{tabular}

(a) Includes tar and water-soluble organics. "tr" indicates that the quantity was less than 1 wt\% of original carbon, and probably less than $0.1 \mathrm{wt} \%$.

(b) Soluble organics not included.

(c) Feed material was densified pine flakes. All other runs with maple/alder headrig sawdust. 
DISTRIBUTION

No. of

Copies

OFFSITE

B. J. Berger

U.S. Department of Energy

Biomass Energy Technology Division

Forrestal Building (DE-321)

1000 Independence Avenue

Washington, DC 20545

2 Simon Friedrich

U.S. Department of Energy

Biomass Energy Technology Division

Forrestal Building (DE-321)

1000 Independence Avenue

Washington, DC 20545

27 DOE Technical Information Center
No. of

Copies

ONSITE

2 DOE Richland Operations Office

H. E. Ransom

D. R. Segna

38 Pacific Northwest Laboratory

E. G. Baker (10)

M. D. Brown

T. D. Chikala

M. A. Gerber

L. K. Mudge (10)

G. F. Schiefelbein (2)

L. J. Sealock, Jr.

G. H. Sewart

D. J. Stevens

P. C. Walkup

P. L. Whiting

W. A. Wilcox

Publishing Coordination (2)

Technical Information (5) 
. 